\title{
Repeated Unpredictable Stress and Antidepressants Differentially Regulate Expression of the Bcl-2 Family of Apoptotic Genes in Rat Cortical, Hippocampal, and Limbic Brain Structures
}

\author{
Therese A Kosten', Matthew P Galloway ${ }^{2}$, Ronald S Duman ${ }^{3}$, David S Russell ${ }^{3}$ and Carrol D'Sa*,1,2,3 \\ 'Department of Psychiatry, Menninger Department of Psychiatry, Baylor College of Medicine and Michael E DeBakey Veterans Affairs, Houston, \\ TX, USA; ${ }^{2}$ Department of Psychiatry and Behavioral Neurosciences, Wayne State University School of Medicine, Detroit, MI, USA; ${ }^{3}$ Laboratory of \\ Molecular Psychiatry, Yale University School of Medicine, New Haven, CT, USA
}

\begin{abstract}
Apoptosis has been proposed as a contributing cellular mechanism to the structural alterations that have been observed in stress-related mood disorders. Antidepressants, on the other hand, are hypothesized to exert trophic and/or neuroprotective actions. The present study examined the regulation of the major antiapoptotic ( $\mathrm{BCl}-2, \mathrm{Bcl}-\mathrm{xl})$ and proapoptotic (Bax) genes by repeated unpredictable stress (an animal model of depression) and antidepressant treatments (ADT). In adult rats, exposure to unpredictable stress reduced Bcl-2 mRNA levels in the central nucleus of the amygdala (CeA), cingulate (Cg), and frontal (Fr) cortices. Bcl-xl mRNA was significantly decreased in hippocampal subfields. In contrast, chronic administration of clinically effective antidepressants from four different classes, ie fluoxetine, reboxetine, tranylcypromine, and electroconvulsive seizures (ECS) upregulated Bcl-2 mRNA expression in the Cg, Fr, and CeA. Reboxetine, tranylcypromine, and ECS selectively increased Bcl-xl, but not Bcl-2 mRNA expression in the hippocampus. Chemical ADT but not ECS, robustly enhanced Bcl-2 expression in the medial amygdaloid nucleus and ventromedial hypothalamus. Fluoxetine did not influence $\mathrm{Bcl}-\mathrm{xl}$ expression in the hippocampus, but it was the only ADT that decreased Bax expression in this region. In the CeA, again in direct contrast to the stress effects, exposure to all classes of ADTs significantly increased Bcl-2 mRNA. The selective regulation of $\mathrm{BCl}-\mathrm{xl}$ and $\mathrm{Bax}$ in hippocampal subfields and of $\mathrm{Bcl}-2$ in the $\mathrm{Cg}$ cortex, amygdala, and hypothalamus suggests that these cellular adaptations contribute to the long-term neural plastic adaptations to stress and ADTs in cortical, hypothalamic, and limbic brain structures.
\end{abstract}

Neuropsychopharmacology (2008) 33, I545- 1558; doi:I0.1038/sj.npp. I30 I527; published online I5 August 2007

Keywords: apoptosis; depression; Bcl-xl; central amygdala; ventromedial hypothalamus

\section{INTRODUCTION}

Despite recent advances, the biological basis of stressrelated psychiatric illnesses, including depression, and the precise mechanism of antidepressant efficacy remain unknown. Evidence linking stress, depression, and antidepressant action suggests that depression is associated with structural impairments as well as a disruption in cellular mechanisms governing neural plasticity (D'Sa and Duman, 2002; Joels et al, 2004; Duman and Monteggia, 2006). Brain imaging studies reveal abnormalities in blood flow in hippocampus, frontal $(\mathrm{Fr})$ cortex, and amygdala in patients with depression (Mayberg, 2003). Volume decreases have been observed in hippocampal, limbic, and

*Correspondence: Dr C D'Sa, Connecticut Mental Health Center, Yale University School of Medicine, 34 Park Street, New Haven, CT 06509, USA, Tel: + I 203974 7688, Fax: + I 203974 7686, E-mail: carrol.dsa@yale.edu

Received 25 September 2006; revised II July 2007; accepted I I July 2007 prefrontal cortical brain regions implicated in the affective and cognitive impairments observed in depression (Manji et al, 2001). Postmortem analyses indicate a reduction in glial cell number and neuronal cell body size in the prefrontal and orbitofrontal cortices (Ongur et al, 1998; Rajkowska et al, 1999) and a decrease in neuronal size in the orbitofrontal cortex (Cotter et al, 2001). A reduction in the size of neuronal cell bodies has also been observed in the hippocampus of patients with depression (Stockmeier et al, 2004). Decreased glial density has also been reported in the amygdala (Bowley et al, 2002; Hamidi et al, 2004) supporting the involvement of the amygdala in depression. These studies indicate that major depression is related to impairments in structural plasticity and cellular atrophy (Duman, 2004). Antidepressant treatment (ADT) is proposed to reverse at least some of these changes, ie the reduction in hippocampal volume (MacQueen et al, 2003; Sheline et al, 2003; Vythilingam et al, 2004).

Stressful life events are major predisposing risk factors for developing depression (McEwen, 2005). In animal stress 
paradigms, stress, and stress hormones decrease neurogenesis in the hippocampus (Gould et al, 1998), modulate apoptosis in the cortex and hippocampus (Lucassen et al, 2001a, 2006), reduce the number and length of apical dendrites of CA3 hippocampal neurons (Magarinos et al, 1996), and induce contrasting patterns of dendritic remodeling in amygdaloid and hippocampal neurons (Vyas et al, 2002; Dulawa and Hen, 2005).

On the other hand, antidepressants are hypothesized to mediate their long-term therapeutic effects by triggering cellular protective mechanisms to counteract the structural impairments (D'Sa et al, 2002; Duman, 2004; Lucassen et al, 2006). In support of this hypothesis, chronic ADT increases the expression of brain-derived neurotrophic factor (BDNF; Nibuya et al, 1995) and neurogenesis in the adult hippocampus (Malberg et al, 2000) as well as enhances cell proliferation in the Fr cortex (Kodama et al, 2004). BDNF infusions into the hippocampus exert antidepressant effects in behavioral models of depression (Shirayama et al, 2002). Chronic, not acute, treatment with the antidepressant tianeptine reverses the stress-induced downregulation of cell proliferation and reductions in hippocampal volume (Czeh et al, 2001).

The cellular mechanisms that underlie the observed neural plasticity and structural impairments in animal models of depression as well as in depressed patients remain unclear. Although excitotoxic cell death (necrosis) is one mechanism of cell death in the adult brain following exposure to stress (for review, see Sapolsky, 2000), research has shown that apoptosis also plays a role (D'Sa and Duman, 2002; Duman, 2004; Lucassen et al, 2006). There is some evidence that apoptosis occurs in depressed patients. Postmortem studies revealed increased hippocampal apoptosis in the enterorhinal cortex and hippocampal subfields (Lucassen et al, 2001b). Recent linkage genetic studies have established a role for APAF1, the gene encoding the protein apoptosis protease-activating factor 1 (Apaf-1), as a chromosome 12 gene that confers predisposition to major depression (Harlan et al, 2006). The depression-linked Apaf-1 alleles share a gain-of-function phenotype in in vitro assay systems supporting an etiologic role for increased apoptosis in depression (Harlan et al, 2006). In animal models, repeated psychosocial stress increased apoptosis in the temporal cortex, but did not alter this process in the dentate gyrus (DG) (Lucassen et al, 2001a). Interestingly, the antidepressant tianeptine reduced apoptosis in the temporal cortex and DG suggesting that antidepressants have cell survival properties (Lucassen et al, 2004).

The apoptotic process is programmed and critically controlled by the balance between pro- (Bax) and anti(Bcl-2, Bcl-xl) apoptotic proteins within the cell (Cory and Adams, 2002). The apoptotic suppressors, Bcl-2 and Bcl-xl, interact with the death-promoting proapoptotic Bax via homo- and heterodimerization in the outer mitochondrial membrane (Lindsten et al, 2005). In response to stress, these proteins regulate the release of cytochrome $c$, which activates caspases, the main executors of apoptosis. An increase in the ratio of pro- $v s$ antiapoptotic proteins is associated with greater vulnerability to apoptotic activation and cell death (Lindsten et al, 2005). Independent of their ability to control cellular survival, Bcl-2 and Bcl-xl antiapoptotic proteins exert pronounced neurotrophic effects (Jonas et al, 2003).
Antidepressants and stress regulate a number of neurotrophic factors involved in cell survival pathways that control Bcl-2 and Bcl-xl expression. These include CREB, $\mathrm{BDNF}$, and MAP kinases and suggest that ADTs mediate their delayed long-term beneficial effects via neurotrophic and cell survival effects (Manji et al, 2001). This raises the question of whether stress and different classes of antidepressants directly regulate the expression of anti- and proapoptotic genes.

There are few reports on the regulation of apoptotic genes in animal stress models and mood disorders. It has been difficult to obtain a clear understanding of the regulation of apoptotic genes/proteins in previous studies due to the different stress paradigms, the duration of the stress response, different methodologies employed to study either gene/ protein (ie immunohistochemistry and nonquantitative western blotting), and the focus solely on one family member at the exclusion of the other apoptotic members. Of interest to the current study are reports demonstrating that a 3-day restraint stress paradigm decreased $\mathrm{Bcl}-2$ immunoreactivity in the hippocampus, whereas poststress 1- or 3-week olanzapine treatment reversed the decrease in the intensity of Bcl-2 staining to pre-stress levels; Bcl-xl and Bax were not examined (Luo et al, 2004). In other reports, repeated immobilization stress increased mRNA expression of the tumor suppressor gene p53 in hippocampal subfields (Nishimura et al, 2004) and decreased Bcl-2 mRNA expression in the hippocampus (Yun et al, 2003). Increased Bcl-2 immunoreactivity in the hippocampus has also been observed following chronic treatment with the antidepressants, amitriptyline and venlafaxine (Xu et al, 2003). As observed with antidepressants, two classical treatments for bipolar disorder, lithium and valproate, upregulated Bcl-2 protein immunoreactivity in cortical regions (Chen et al, 1999). Most of these studies have focused solely on Bcl-2 immunoreactivity in the cerebral cortex and/or hippocampus. Less is known about stress and $\mathrm{ADT}$ regulation of the $\mathrm{Bcl}-\mathrm{xl}$ and Bax family members and more importantly, whether molecular adaptations at the level of gene expression occur in other limbic brain areas thought to play a role in depression.

The primary goals of this study were: (1) to examine the influence of a 10-day repeated unpredictable stress (RUS) paradigm (Willner et al, 1992; Ortiz et al, 1996; Perrotti et al, 2004) on expression of Bcl-2, Bcl-xl, and Bax mRNAs and (2) to investigate whether treatment with clinically effective antidepressants from distinct pharmacological classes, as well as repeated electroconvulsive seizures (ECS), regulates expression of the apoptotic genes. We extend our analyses from cortex and hippocampus to include previously uncharacterized hypothalamic-limbic brain regions. Our results demonstrate that stress and ADT differentially regulate expression of these genes in brain structures implicated in the etiology and treatment of depressive disorders.

\section{MATERIALS AND METHODS}

\section{Animals}

Male Sprague-Dawley rats (200-250 g; Charles River, Wilmington, MA) were housed in groups of two and given food and water ad libitum in a $12 \mathrm{~h}$ light/dark cycle. All 
protocols were approved by Yale University and performed in accordance with the National Institute of Health Guide for the Care and use of Laboratory Animals.

\section{Stress and Drug Treatments}

RUS involves rats being exposed to two of eight different stressors twice daily (forced swim, restraint stress, overnight lights, etc). The stressors, which varied from day to day for a period of 10 days, were administered according to an established paradigm (Willner et al, 1992; Ortiz et al, 1996; Perrotti et al, 2004). This stress paradigm has been previously shown to produce profound effects on a number of cellular, biochemical, and neurochemical end points (Willner et al, 1992; Ortiz et al, 1996; Perrotti et al, 2004). The influence of this 10-day stress paradigm on increasing plasma corticosterone levels has been reported previously (Haile et al, 2001). Control groups were kept in their home cages for the 10-day period.

For the chronic pharmacological ADT, groups of rats ( $n=5-7$ per group) were administered fluoxetine $(5 \mathrm{mg} / \mathrm{kg}$; once daily), reboxetine $(20 \mathrm{mg} / \mathrm{kg}$ twice daily) for 21 days or tranylcypromine $(7.5 \mathrm{mg} / \mathrm{kg}$ once daily for 10 days, then $10 \mathrm{mg} / \mathrm{kg}$ for 11 days) or the corresponding vehicle via intraperitoneal injections (i.p.). For the chronic ECS treatments, rats $(n=5)$ were administered (once daily) ECS via ear-clip electrodes $(60 \mathrm{~mA}, 0.3 \mathrm{~s})$ or received sham treatment (handled identically as those that received ECS but without electrical stimulation). The stressed and chemical ADT animals were decapitated $2 \mathrm{~h}$ after the last treatment, the chronic ECS group was decapitated $6 \mathrm{~h}$ after the last treatment (this time point was chosen due to the availability of tissue), brains were removed and frozen on dry ice. For the RNAse protection assay (RPA) studies, the stress, fluoxetine, and tranylcypromine groups were decapitated $2 \mathrm{~h}$ after the last treatment, Fr cortical and hippocampal tissue were quickly dissected, frozen on dry ice, and stored at $-80^{\circ} \mathrm{C}$ until analyses.

\section{Riboprobes}

The partial cDNAs used as templates for riboprobe generation were generated by RT-PCR amplification using rat spleen and thymus cDNA as templates and Bcl-2-, Bcl$\mathrm{xl}-$, and Bax-specific primers with a T7 promoter sequence appended to the corresponding $-3^{\prime}$ primer as previously described (Gold et al, 1997). The cDNAs were confirmed by sequencing (Keck Facility, Yale University, CT).

The Bcl-2 plasmid contained a $270 \mathrm{bp}$ fragment of the rat bcl-2 mRNA sequence (nucleotides 515-785 of accession no. L14680). The Bcl-xl plasmid contained a $275 \mathrm{bp}$ fragment of the rat Bcl-xl mRNA sequence (nucleotides 445-720 of accession no. U72350.1). The Bax plasmid contained a $272 \mathrm{bp}$ fragment of a highly conserved region of the rat Bax1 mRNA sequence (nucleotides 301-573 of accession no. U49729). Antisense ${ }^{35}$ S-labeled riboprobes were transcribed from $1 \mu \mathrm{g}$ of the PCR product using T7 RNA polymerase in the presence of ${ }^{35} \mathrm{~S}$-CTP. Riboprobes were purified using Roche spin columns and used for in situ hybridization (ISH) and RPA.

\section{In Situ Hybridization Analysis}

Frozen brains $(n=4-5$ for the stress ISH studies and $n=$ 5-6 for the chronic ADT ISH studies) were sectioned on the cryostat at $14 \mu \mathrm{m}$ ( 1 in 12 series) and stored at $-80^{\circ} \mathrm{C}$. Frozen sections were fixed in $4 \%$ paraformaldehyde, washed in PBS, and treated with $0.25 \%$ acetic anhydride. Sections were dehydrated in increased ethanol gradients and air dried. ISH was carried out overnight at $60^{\circ} \mathrm{C}$ in hybridization buffer with ${ }^{35}$ S-labeled cRNA probe at $1.0 \times 10^{6}$ c.p.m./ slide. The sections were washed stringently in $4 \times$ SSC containing $10 \mathrm{mM}$ sodium thiosulfate $\left(60^{\circ} \mathrm{C}\right)$, treated with RNAse A ( $20 \mu \mathrm{g} / \mathrm{ml}$ for $30 \mathrm{~min})$ followed by descending SSC concentrations to a stringency of $0.1 \times$ SSC at $60^{\circ} \mathrm{C}$. The sections were briefly dipped in $95 \%$ ethanol, air dried, and exposed to $\beta$-max Hyperfilm for 4, 7, 14, and 17 days.

\section{RNAse Protection Assays of Bcl-2, Bcl-xl, and Bax mRNAs in Frontal Cortical and Hippocampal Tissues}

Total RNA was extracted from Fr cortical or hippocampal tissue from rats $(n=7$ for the stress studies and $n=6$ for the chronic ADT RPA studies) using the RNAqueous kit (Ambion). ${ }^{32}$ P-CTP-labeled antisense Bcl-2, Bcl-xl, and Bax riboprobes (used for the ISH) were generated using T7 RNA polymerase. The RPA was performed according to the manufacturer's standard protocol with the RPA III kit (Ambion) using $20 \mu \mathrm{g}$ of total RNA to detect Bcl-2 and $10 \mu \mathrm{g}$ to detect Bcl-xl and Bax according to previously published procedures (D'Sa et al, 2002). Unhybridized probes were removed by RNAse A-T1 digestion. Hybridized probes were visualized via autoradiography following denaturing PAGE.

\section{Data Analysis}

For analysis, levels of mRNAs were determined by outlining the layers of the cortex, central nucleus of the amygdala $(\mathrm{CeA})$, medial amygdaloid nucleus (MeA), ventromedial hypothalamus (VMH), CA1-CA3, and DG layers of hippocampus on film autoradiograms of the ISH sections, or the corresponding band on RPA autoradiograms, followed by quantification of these areas on the NIH Image analysis program. Labeling densities for each region studied were taken from each brain section per animal (both hemispheres). Polynomial calibration curves were fitted to relative optical density values measured from known ${ }^{14} \mathrm{C}$-labeled radioactive step standards (Amersham) that were coexposed to the film along with the brain tissue sections (Gold et al, 1997). For the Bcl-xl and Bax film autoradiograms, analysis was done on films exposed to the slides for 4 days. For analysis of the Bcl-2 film autoradiograms, due to low expression of Bcl-2 mRNA in the adult brain, for the stress experiments, analysis was done on films exposed to slides for 7 days. In experiments concerning ADT, for analysis of the Bcl-2 film autoradiograms, in the hippocampus, analysis was done on the 17-day films, in the MeA and VMH, analysis were done on the 14-d films.

Because mRNA transcript expression is dependent on the level being examined, levels were matched between control and treated animals, as closely as possible. From 
each animal, for the anterior cingulate $(\mathrm{Cg})$ and lateral Fr cortices, five brain sections corresponding to bregma $+2.14,+2.28,+2.42,+2.56$, and $+2.7 \mathrm{~mm}$ were analyzed; for the parietal cortex, CA1-CA3, DG hippocampal subfields, three brain sections corresponding to bregma -4.02 , -3.6 , and $-3.18 \mathrm{~mm}$ were analyzed; for the $\mathrm{MeA}$ and the $\mathrm{VMH}$, four brain sections corresponding to bregma -2.62 , $-2.67,-2.73$, and $-2.78 \mathrm{~mm}$ were analyzed; for the CeA, six brain sections corresponding to bregma -2.28, -2.34 , $-2.39,-2.45,-2.50$, and $-2.56 \mathrm{~mm}$ were analyzed; the SEM for each animal was determined. Experiments containing two groups were subjected to a two-tailed $t$-test, with a significance level of $p<0.05$.

\section{Cresyl Violet Staining}

Cresyl violet staining on adjacent cryostat cut sections was carried out according to published procedures (Gold et al, 1997). Briefly, sections were dehydrated in an alcohol series, rehydrated in distilled water, and stained in $0.3 \%$ cresyl violet solution for $15 \mathrm{~s}$. After brief rinses in distilled water, followed by alcohol gradients, sections were mounted with Permount and observed by light microscopy.

\section{RESULTS}

\section{Regulation of Bcl-2, Bcl-xl, and Bax mRNAs by Repeated Unpredictable Stress: In Situ Hybridization Studies}

In initial studies, we focused our analyses on the regulation of Bcl-2, Bcl-xl, and Bax mRNA expression from rats subjected to RUS for 10 days. This paradigm, rather than the daily restraint stress paradigm, was chosen to circumvent the possibility of rats habituating to repeated exposure to the same stressful stimulus (Ortiz et al, 1996).

As illustrated in Figure $1 \mathrm{a}$ and b, exposing rats to a 10-day period of unpredictable stress significant decreased Bcl-2 mRNA levels in rat $\mathrm{Cg}(25 \% ; t=2.86 ; p=0.02)$ and lateral Fr $(21 \% ; t=3.24 ; p=0.017)$ cortices. Bcl-2 was present at lower levels in the adult hippocampus and no detectable changes in expression were seen in this region. During our ISH studies, in control rat sections, we observed a a
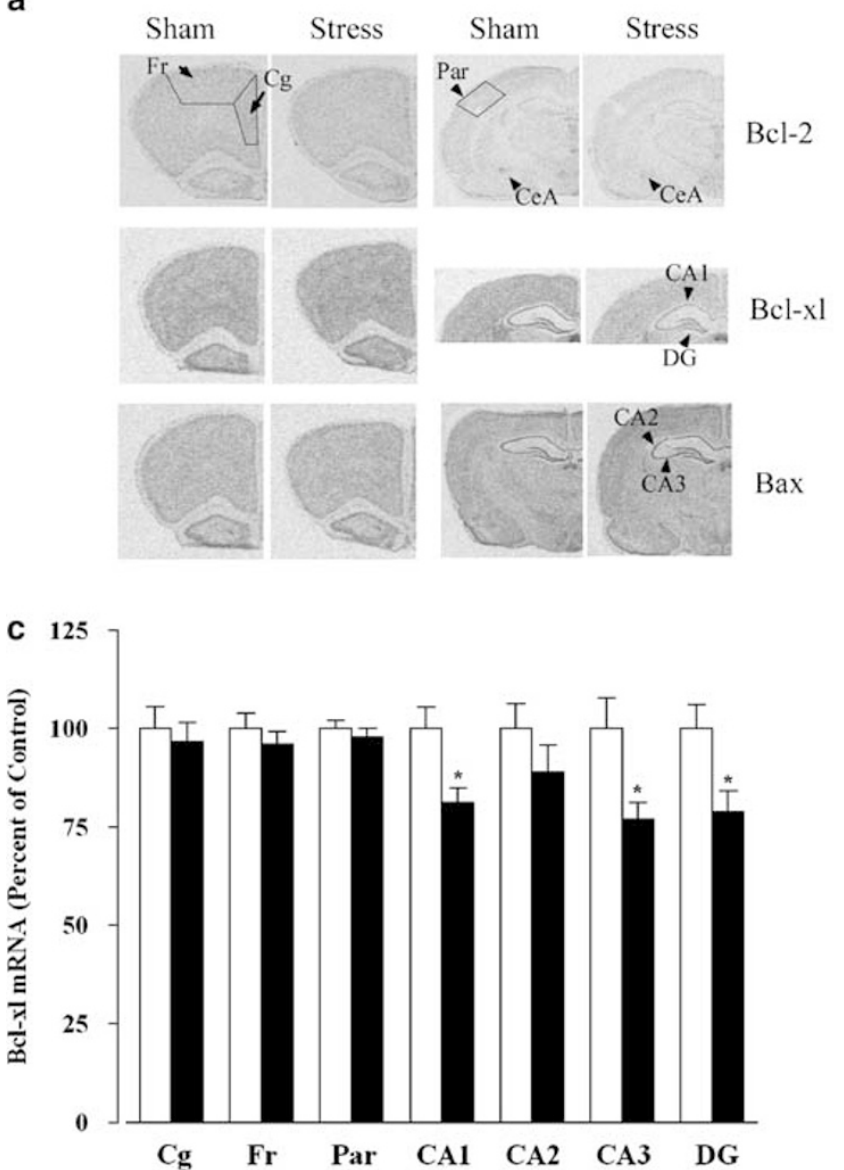
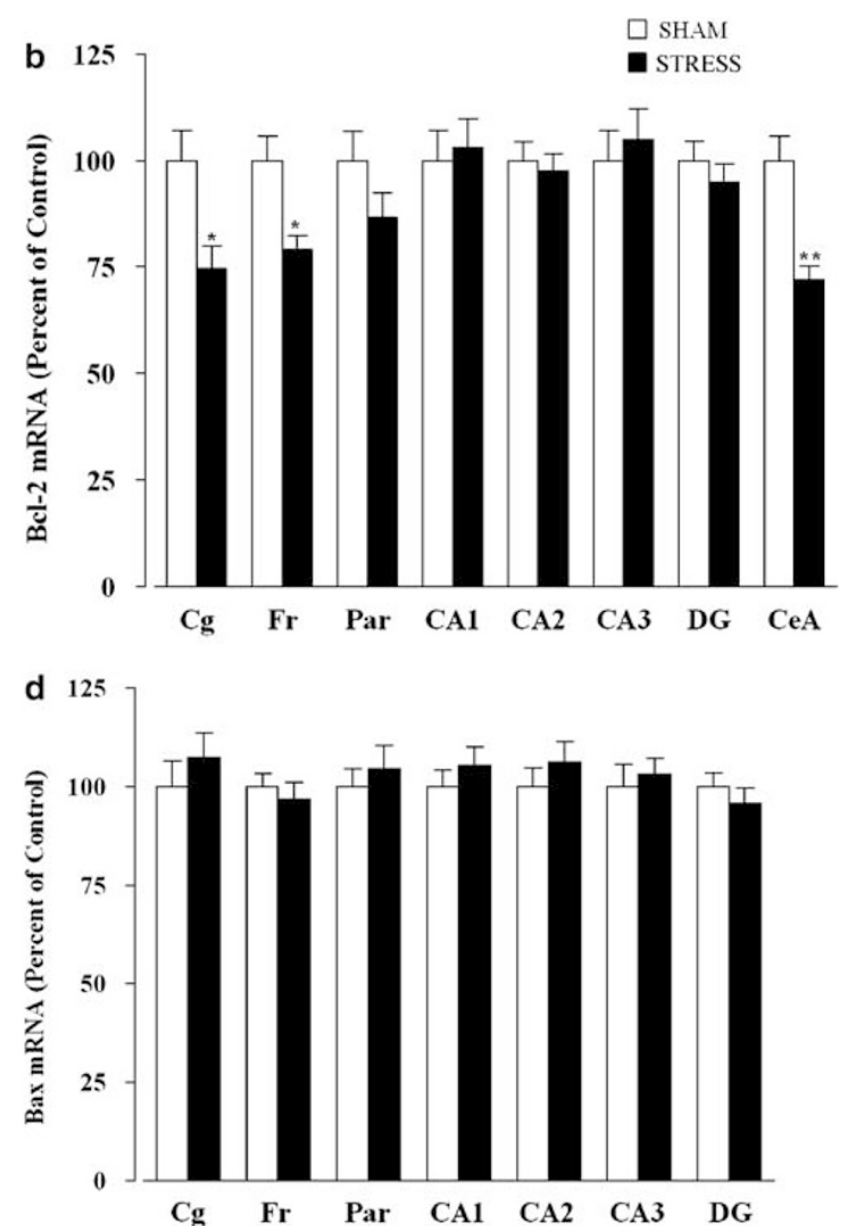

Figure I RUS decreases levels of Bcl-2 mRNA in $\mathrm{Cg}$ and $\mathrm{Fr}$ cortical regions and in CeA. Stress downregulates levels of Bcl-xl mRNA in hippocampal subfields (CAI, CA3, and DG). Representative film autoradiograms of Bcl-2 mRNA expression in the Cg, Fr cortices, CeA, and hippocampus; of Bcl-xl mRNA expression in the cortex and CAI-CA3 and DG; of Bax mRNA expression in the cortex and hippocampus in control rats or those treated with RUS for 10 days are presented in (a). The quantitative analysis of $\mathrm{Bcl}-2, \mathrm{Bcl}-\mathrm{xl}$, and Bax mRNA expression is shown in (b), (c), and (d), respectively, expressed as the percentage of change from the control $\pm \operatorname{SEM}(n=4$, * $p<0.05$; ** $p<0.01$, two-tailed $t$-test). Cg, cingulate cortex; Fr, lateral frontal cortex; Par, parietal cortex; CeA, central nucleus of the amygdala; CAI-CA3, pyramidal cell layers of the hippocampus; DG, dentate gyrus hippocampal layer (scale $\operatorname{bar}=1.6 \mathrm{~mm})$ 
prominent pattern of restrictive Bcl-2 mRNA expression in the $\mathrm{CeA}$. The CeA was identified by cresyl violet staining on adjacent cryostat-cut sections. Interestingly, we found that RUS markedly decreased Bcl-2 mRNA by $28 \%$ in the CeA $(t=4.22 ; p=0.005)$ (Figure $1 \mathrm{a}$ and $\mathrm{b})$.

In contrast to Bcl-2 mRNA expression, in control sections, Bcl-xl and Bax mRNAs were highly expressed in hippocampal cell layers (Figure 1a). Bcl-xl mRNA was significantly diminished by chronic stress in the CA1 (19\%; $t=2.85 ; p=0.029)$, CA3 $(23 \% ; t=2.56 ; p=0.042)$ pyramidal layers, and DG granule cell layer (21\%; $t=2.62$; $p=0.039$ ) (Figure 1a and c). Bcl-xl mRNA was unchanged in cortical regions, Bax mRNA levels were not changed in the brain regions examined (Figure 1d). Based on ISH results obtained using sense and antisense cRNAs, we concluded that we were unable to detect specific Bax and Bcl-xl cRNA labeling in the CeA.

\section{Regulation of Bcl-2, Bcl-xl, and Bax mRNA Levels by Chronic Fluoxetine Administration}

We next studied whether clinically effective antidepressants would influence expression of the apoptotic genes. We initially characterized long-term effects of the commonly used serotonin-selective reuptake inhibitor, fluoxetine. In cortical, amygdaloid and hippocampal brain regions, fluoxetine-induced changes in mRNA expression were opposite to those observed for stress. For example, in the anterior $\mathrm{Cg}$ cortex, there was a $27 \%$ upregulation in $\mathrm{Bcl}-2$ mRNA expression $(t=2.78 ; p=0.027)$; similar increases a
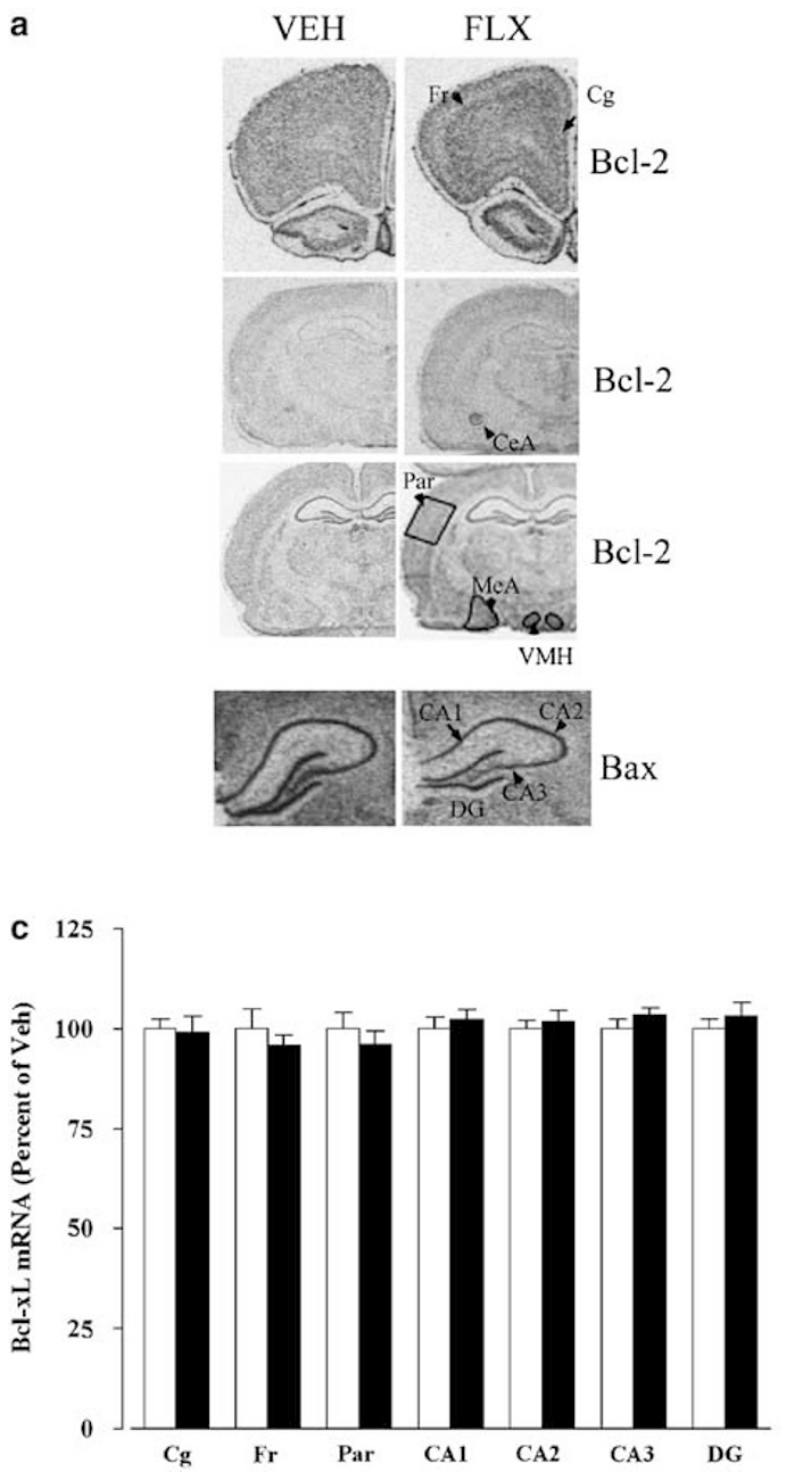

b
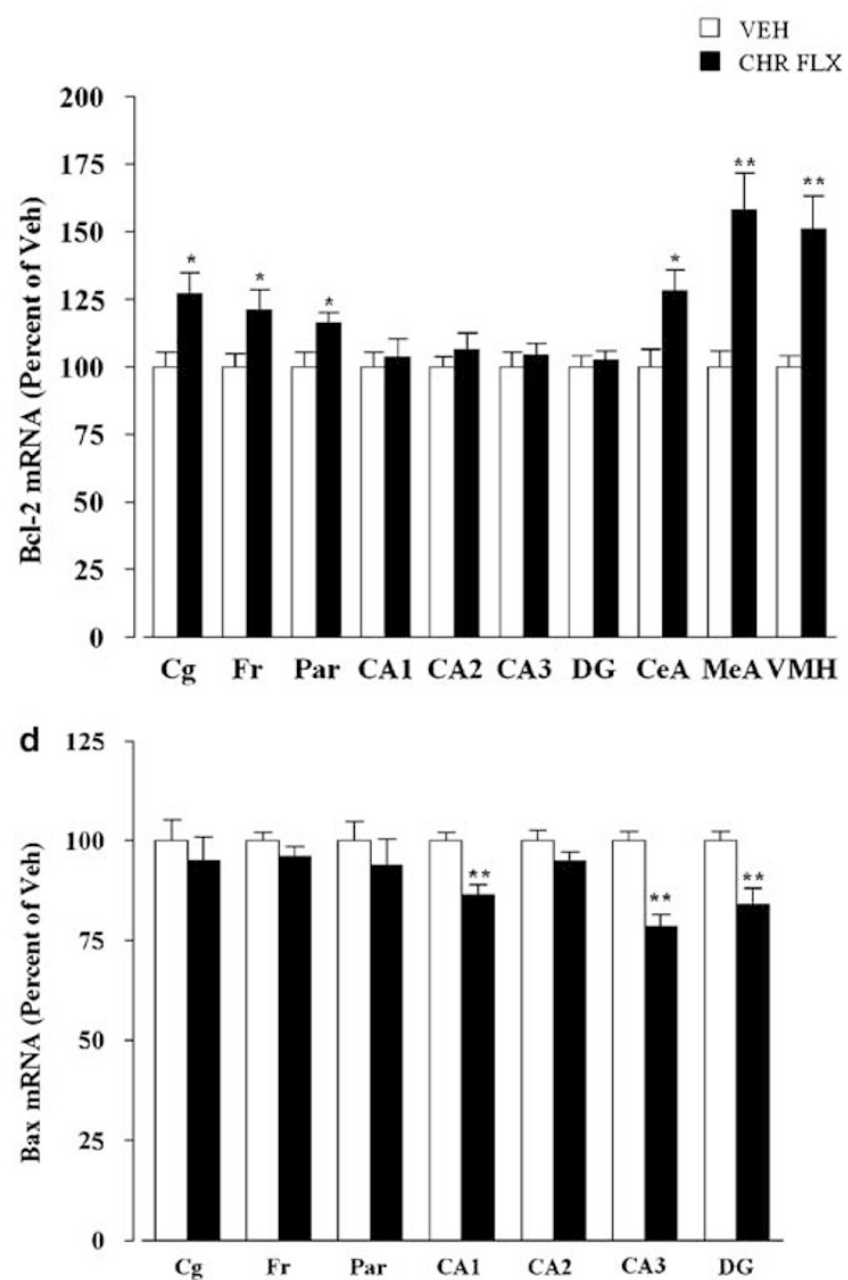

Figure 2 Chronic fluoxetine treatment increases $\mathrm{Bcl}-2 \mathrm{mRNA}$ expression in the $\mathrm{Cg}$, lateral $\mathrm{Fr}$ and parietal cortices, CeA, MeA and $\mathrm{VMH}$, and downregulates Bax mRNA expression in the CAI, CA3, and DG hippocampal layers. Representative film autoradiograms of Bcl-2 mRNA expression in the $\mathrm{Cg}$, Fr cortices, CeA, MeA, and VMH; of Bax mRNA expression in the CAI, CA3, and DG in control rats or those treated with chronic fluoxetine for $2 \mathrm{I}$ days are shown in (a). The quantitative analysis of $\mathrm{Bcl}-2, \mathrm{Bcl}-\mathrm{xl}$, and Bax mRNA expression is shown in (b), (c), and (d), respectively, expressed as the percentage of change from the control $\pm \operatorname{SEM}(n=6$, *p $<0.05$; ** $p<0.01$, two-tailed $t$-test). Cg, cingulate cortex; Fr, lateral frontal cortex; Par, parietal cortex; CAI-CA3, pyramidal cell layers of the hippocampus; DG, dentate gyrus hippocampal layer; CeA, central nucleus of the amygdala; MeA, medial amygdaloid nucleus; VMH, ventromedial hypothalamus (scale bar $=1.8$ and $0.9 \mathrm{~mm}$ ). 
were observed in the lateral Fr neocortex $(21 \% ; t=2.34$; $p=0.04)$. In cortical regions, we found that the effects of fluoxetine were more global and included significant changes in the parietal cortex $(16 \% ; t=2.48 ; p=0.038$; Figure $2 \mathrm{a}$ and $\mathrm{b})$. Chronic fluoxetine treatment also led to a marked upregulation in Bcl-2 mRNA levels in the CeA $(28 \% ; t=2.70 ; p=0.027)$ (Figure $2 \mathrm{a}$ and $\mathrm{b})$. An examination of the fluoxetine-treated ISH brain sections after exposing film autoradiograms for 14 days revealed that this drug regimen profoundly induced $\mathrm{Bcl}-2 \mathrm{mRNA}$ in two discrete brain nuclei, the MeA and VMH (Figure $2 \mathrm{a}$ and $\mathrm{b}$ ). The CeA, $\mathrm{MeA}$, and $\mathrm{VMH}$ were identified from the Paxinos and Watson Altas (Paxinos and Watson, 1986) on cresyl violet staining performed on adjacent cryostat-cut sections. The 21-day regimen of chronic fluoxetine administration markedly increased Bcl-2 mRNA expression by $58 \%$ in the MeA $(t=3.91 ; p=0.005)$ and by $51 \%$ in the VMH $(t=3.89$; $p=0.004)$ (Figure $2 \mathrm{a}$ and $\mathrm{b}$ ). In contrast, fluoxetine did not influence Bcl-2 mRNA expression in the hippocampus and had no discernible effect on Bcl-xl mRNA levels in the cortex and hippocampus (Figure 2c).
Densitometric analyses of Bax mRNA expression revealed an interesting pattern of regulation. As seen in Figure 2, a small but significant decrease of $14 \%$ in the CA1 $(t=4.09$; $p=0.002), 22 \%$ in the CA3 $(t=4.94 ; p=0.005)$, and $16 \%$ in DG $(t=3.39 ; p=0.007)$ in Bax mRNA levels was detected (Figure 2d). Fluoxetine treatment did not influence Bax levels in the cortex.

\section{Regulation of Bcl-2, Bcl-xl, and Bax mRNA Levels by Chronic Reboxetine Administration}

Regulation of the apoptotic genes by chronic administration of the norepinephrine-selective reuptake inhibitor reboxetine was next examined. Among the cortical areas analyzed, a significant increase in Bcl-2 mRNA expression with repeated reboxetine treatment was seen mainly in the $\mathrm{Cg}(24 \% ; t=3.19 ; p=0.010)$ and $\mathrm{Fr}(14 \% ; p=2.36$; $t=0.041$ ) (Figure $3 \mathrm{a}$ and $\mathrm{b}$ ) cortices, but not in the parietal cortex. Similar to the increases observed with fluoxetine treatment, reboxetine dramatically upregulated $\mathrm{Bcl}-2$ mRNA by $27 \%$ in the CeA $(t=3.09 ; p=0.012), 66 \%$ in the
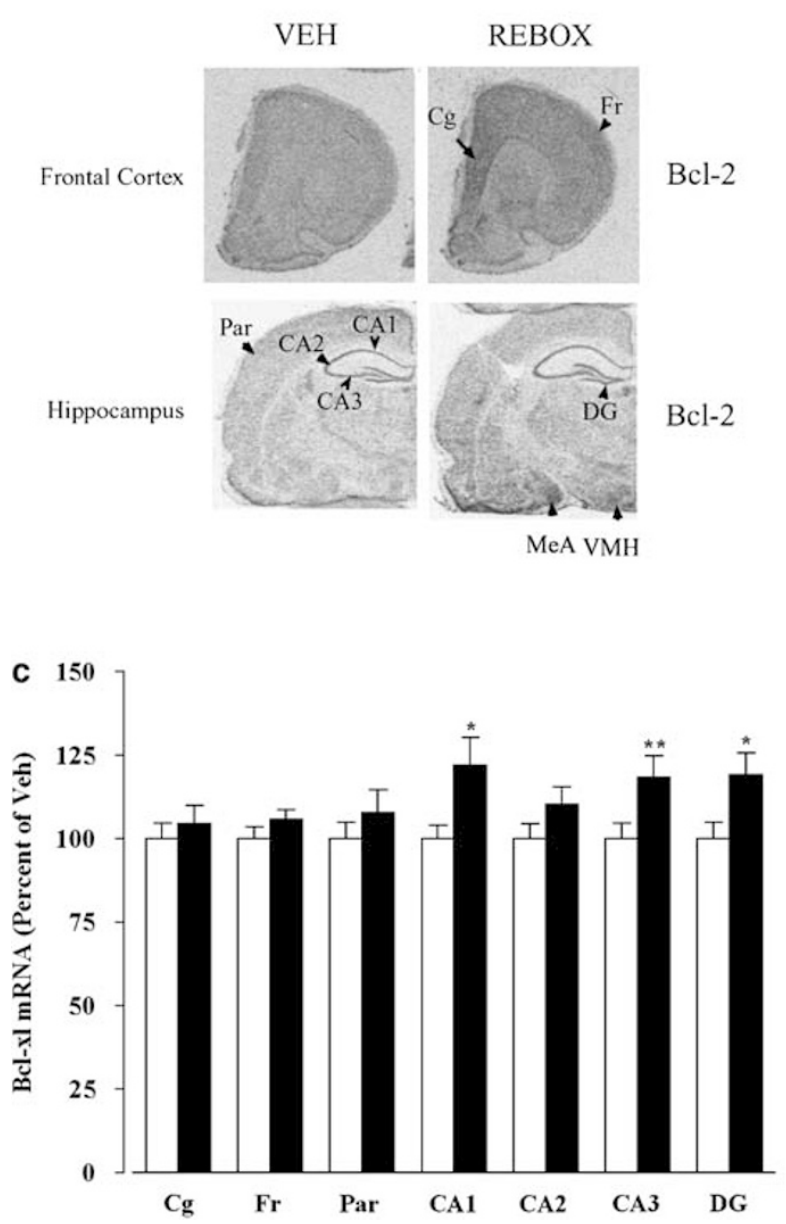

b

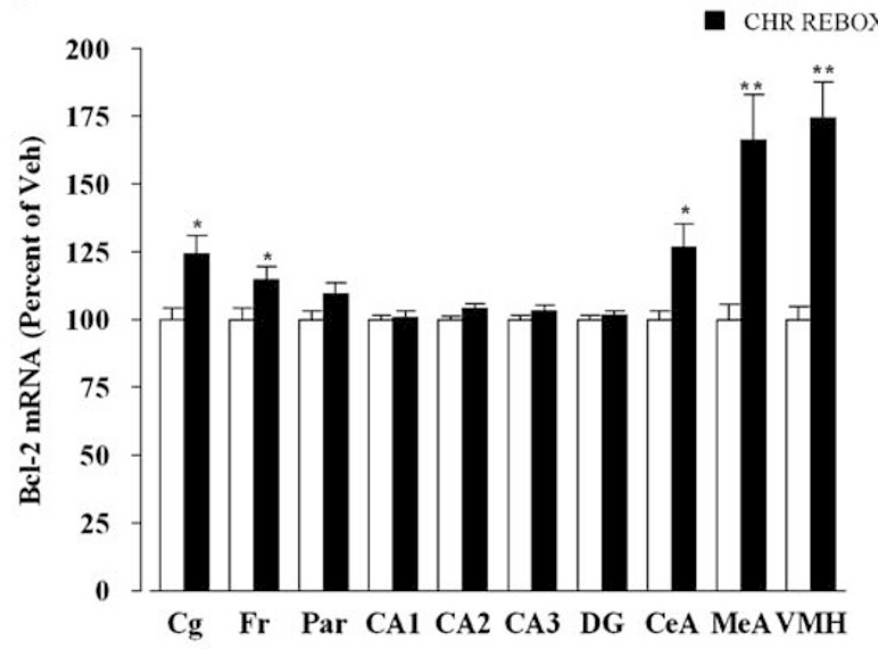

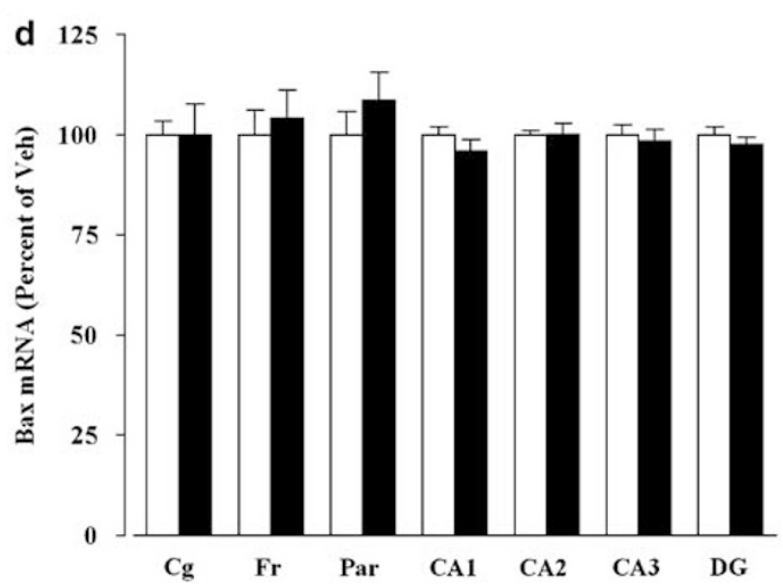

Figure 3 Chronic reboxetine treatment increases $\mathrm{Bcl}-2 \mathrm{mRNA}$ expression in the $\mathrm{Cg}$ and Fr cortices, $\mathrm{CeA}, \mathrm{MeA}$ and $\mathrm{VMH}$, and increases $\mathrm{Bcl}-\mathrm{xl} \mathrm{mRNA}$ expression in the CAI, CA3, and DG hippocampal subfields. (a) Representative film autoradiograms of Bcl-2 mRNA expression in the Cg and Fr cortices, $\mathrm{MeA}$, and $\mathrm{VMH}$ in control rats or those treated with chronic reboxetine (2I days). The quantitative analysis of $\mathrm{Bcl}-2$ (b), Bcl-xl (c), and $\mathrm{Bax}$ mRNA expression (d) is expressed as the percentage of change from the control \pm SEM ( $n=5-6,{ }^{*} p<0.05$; $* *$ $p<0.0$ I, two-tailed $t$-test). Cg, cingulate cortex; Fr, lateral frontal cortex; Par, parietal cortex; CA I-CA3, pyramidal cell layers of the hippocampus; DG, dentate gyrus hippocampal layer; CeA, central nucleus of the amygdala; MeA, medial amygdaloid nucleus; $\mathrm{VMH}$, ventromedial hypothalamus (scale bar $=1.6 \mathrm{~mm}$ ). 
MeA $(t=3.64 ; p=0.006)$, and $74 \%$ in the $\mathrm{VMH}(t=5.74$; $p=0.0002$ ) (Figure $3 a$ and $b$ ).

Reboxetine had no effect on Bcl-xl mRNA expression in cortical regions. However, significant differences were observed in the hippocampus, particularly in the CA1 (22\%; $t=2.54 ; p=0.03), \mathrm{CA} 3(18 \% ; t=2.85 ; p=0.009)$, and DG (19\%; $t=2.45 ; p=0.037)$ cell layers (Figure $3 c$ ). Reboxetine administration had no influence on Bax mRNA levels in either cortical or hippocampal regions (Figure 3d).

\section{Regulation of Bcl-2, Bcl-xl, and Bax mRNA Levels by Chronic Tranylcypromine Administration}

The influence of another class of antidepressant, the monoamine oxidase inhibitor tranylcypromine, on mRNA expression levels of the Bcl-2 family members was determined. Mirroring the effects observed with reboxetine, chronic administration of tranylcypromine increased Bcl-2 mRNA by $24 \%$ in the Cg cortex $(t=3.73 ; p=0.006), 18 \%$ in the superficial layers of the Fr cortex $(t=2.84 ; p=0.023)$, and by $22 \%$ in the CeA $(t=2.92 ; p=0.017)$ (Figure $4 \mathrm{a}$ and b). Again, a dramatic induction of 69 and $87 \%$ was observed in the MeA and VMH $(t=3.77 ; p=0.005, t=6.07$; $p<0.0002$ ) (Figure $4 \mathrm{~b}$ ).

An examination of $\mathrm{Bcl}-\mathrm{xl}$ mRNA expression revealed significant changes in the $\mathrm{CA} 1$ and $\mathrm{CA} 2$ regions $(18 \%$; $t=2.67 ; p=0.026,17 \% ; t=2.39 ; p=0.04)$. Additionally, an increase of $15 \%$ in the CA3 $(t=4.39 ; p=0.002)$ and of $24 \%$ in the DG $(t=3.94 ; p=0.003)$ was also observed (Figure $4 \mathrm{c})$. Different from the upregulation observed with fluoxetine treatment, tranylcypromine did not alter levels of Bax mRNA levels in the hippocampus (Figure 4d).

\section{Regulation of Bcl-2, Bcl-xl, and Bax mRNA Levels by Chronic ECS}

To examine the possibility that changes in Bcl-2, Bcl-xl, and Bax mRNAs also occur in response to a nonchemical ADT, we examined the influence of chronic ECS on mRNA expression. ECS is clinically the most effective treatment for refractory depression and is only efficacious after chronic administration. a
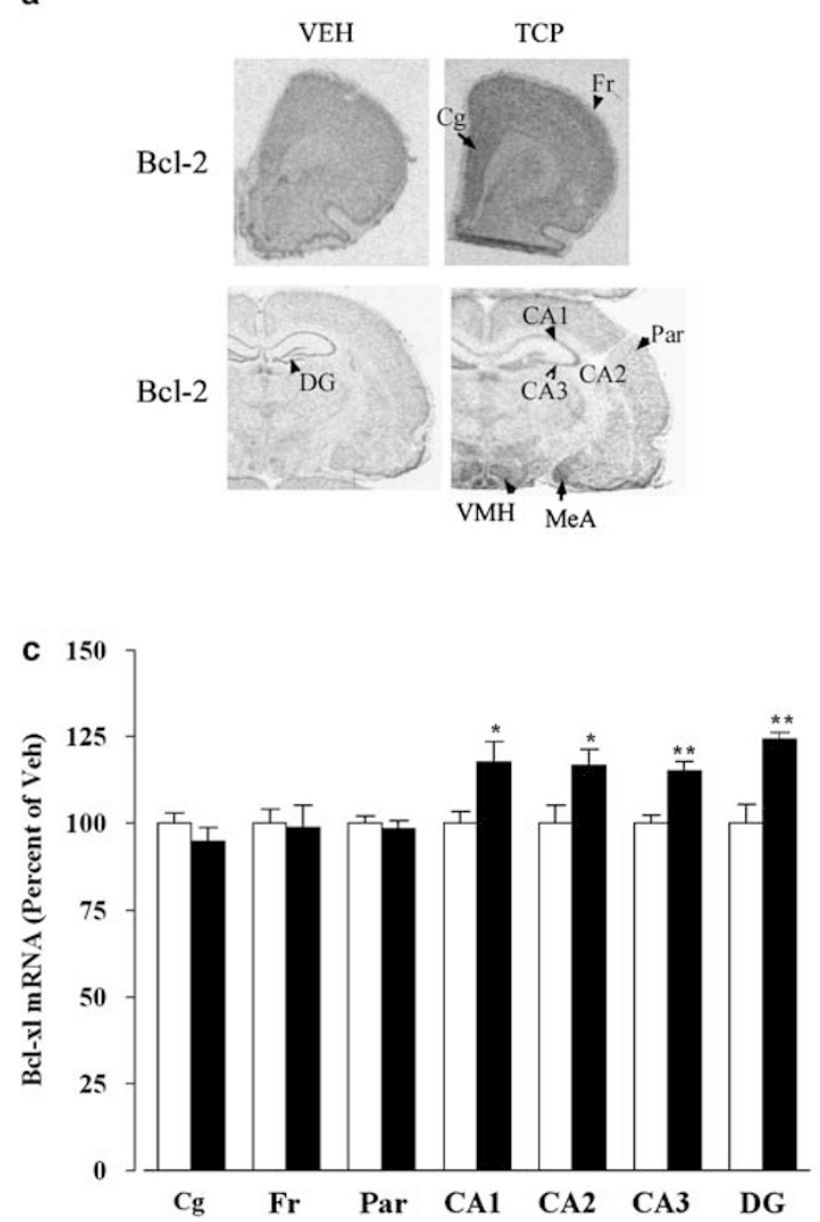
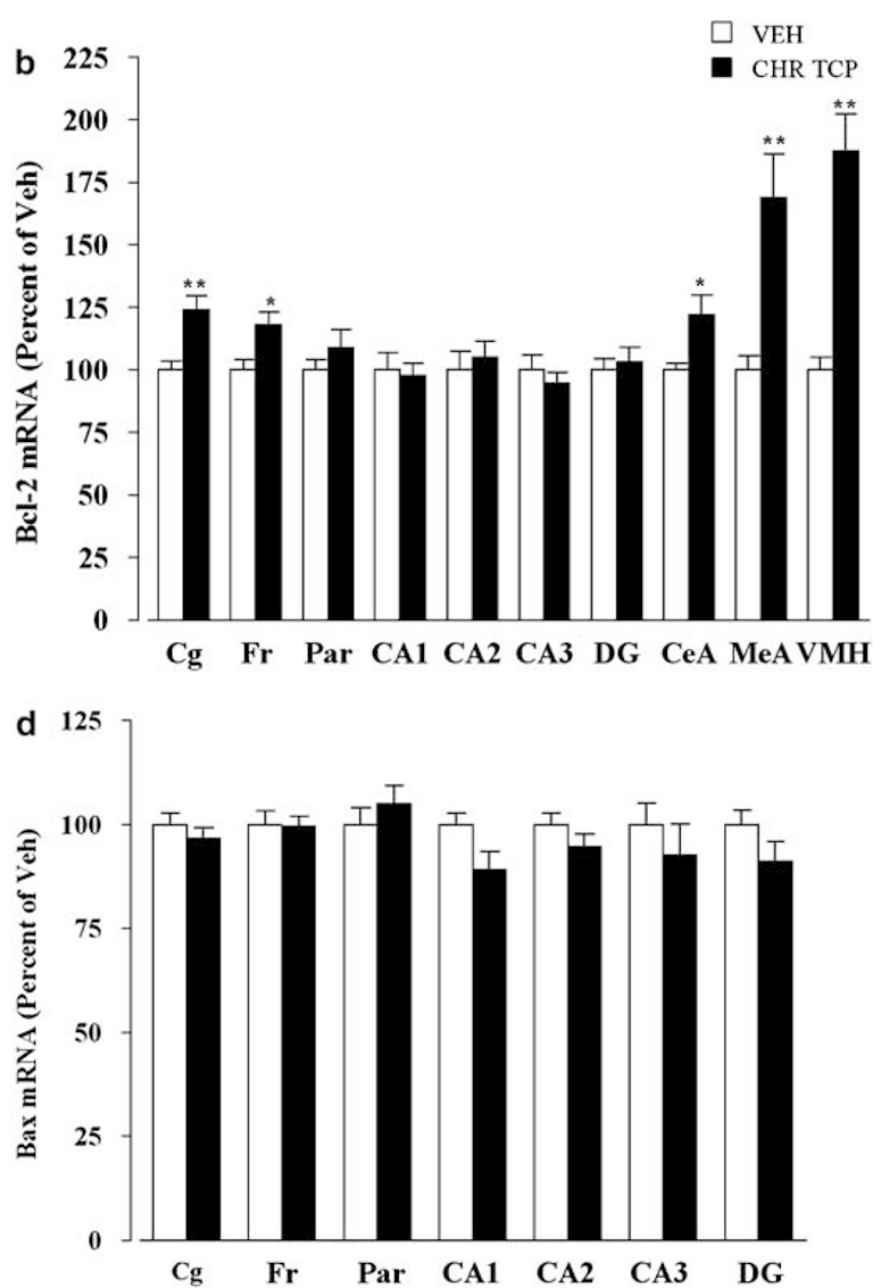

Figure 4 Chronic tranylcypromine treatment upregulates $\mathrm{Bcl}-2$ mRNA expression in the $\mathrm{Cg}$ and lateral $\mathrm{Fr}$ cortical areas, CeA, MeA and VMH, and enhances $\mathrm{Bcl}-\mathrm{xl}$ mRNA expression in the CAI, CA2, CA3, and DG hippocampal subfields. Representative film autoradiograms of Bcl-2 mRNA expression in the $\mathrm{Cg}$ and Fr cortex, MeA, and $\mathrm{VMH}$ and hippocampus are shown in (a). The quantitative analysis of $\mathrm{Bcl}-2, \mathrm{Bcl}-\mathrm{xl}$, and Bax mRNA expression is shown in (b), (c), and (d), respectively, expressed as the percentage of change from the control \pm SEM $(n=6, * p<0.05$; *** $<0.0$ l, two-tailed $t$-test). Cg, cingulate cortex; Fr, lateral frontal cortex; Par, parietal cortex; CA I-CA3, pyramidal cell layers of the hippocampus; DG, dentate gyrus hippocampal layer; CeA, central nucleus of the amygdala; MeA, medial amygdaloid nucleus; $\mathrm{VMH}$, ventromedial hypothalamus (scale bar $=1.6 \mathrm{~mm}$ ). 
Interestingly, in contrast to chemical ADT, labeling densities for Bcl-2 remained unchanged by chronic ECS in the MeA and VMH. Mirroring the global effects of fluoxetine in cortical regions, ECS (10 days) resulted in significant changes in levels of Bcl-2 mRNA in the anterior $\mathrm{Cg}(33 \% ; t=5.3 ; p=0.002)$, lateral $\mathrm{Fr}(28 \% ; t=4.43$; $p=0.004)$, and parietal $(24 \% ; t=2.5 ; p=0.036)$ cortices. An upregulation of Bcl-2 was seen in the CeA $(32 \% ; t=4.74$; $p=0.001$ ) (Figure 5a).

An examination of Bcl-xl mRNA by chronic ECS revealed significant increases of $20 \%$ in the CA1 $(t=5.02 ; p=0.002)$ and $27 \%$ in the DG $(t=4.77 ; p=0.003)$ (Figure $5 \mathrm{~b}$ ). No prominent changes in Bcl-xl expression were observed in other brain regions. Chronic ECS did not have significant effects on Bax mRNA levels (Figure $5 c$ ).

A summary of the stress and ADT regulation of apoptotic gene expression by ISH is given in Table 1.

RNAse Protection Analysis of Bcl-2, Bcl-xl, and Bax mRNAs in Frontal Cortex and Hippocampus: Regulation by Stress, Fluoxetine, and Tranylcypromine

Regulation of apoptotic protein mRNAs was further examined by RNAse protection analyses of dissected brain tissue. The riboprobes designed for RNAse protection protect $270 \mathrm{bp}$ of Bcl-2 mRNA, $275 \mathrm{bp}$ of Bcl-xl mRNA, and $272 \mathrm{bp}$ of Bax mRNA, respectively.

We initially examined the regulation of these mRNAs following exposure to the RUS paradigm (Figure 6a). The ISH results demonstrated that the most consistent regulation of Bcl-2 and Bcl-xl mRNAs was observed in the $\mathrm{Cg}$ and Fr cortices and hippocampus, respectively; hence this is where we focused our RPA studies. The Fr corticaldissected tissue used for our studies included the anterior Cg cortical regions.

Similar to the changes observed in our quantitative ISH studies, exposure to the 10-day RUS paradigm significantly decreased the expression of Bcl- 2 by $43 \%$ in rat Fr cortex $(t=2.45 ; p=0.03)$. Bcl-xl and Bax expression was unchanged (Figure 6a and b). In hippocampal tissue, levels of Bcl-xl, and not Bcl-2 or Bax, were robustly downregulated by $38 \%$ in response to RUS ( $t=3.55 ; p=0.004)$, effects that were consistent with the ISH results.

We next performed RPA analysis on repeated fluoxetinetreated rat brain tissue. Administration of fluoxetine for 21 days significantly increased levels of Bcl-2 mRNA by $53 \%$ in the Fr cortex $(t=2.66 ; p=0.024)$. An examination of Bax levels in the hippocampus revealed that fluoxetine downregulated its expression levels by $36 \%(t=2.66 ; p=0.024)$. $\mathrm{Bcl}-\mathrm{xl}$ expression was not influenced in the Fr cortex or hippocampus by fluoxetine treatment (Figure 6c).

We also examined regulation of $\mathrm{Bcl}-2, \mathrm{Bcl}-\mathrm{xl}$, and $\mathrm{Bax}$ mRNAs following administration of the chemical ADT, tranylcypromine. RPA analysis showed that rats treated with the MAO-inhibitor antidepressant, had higher levels of Bcl-2 in the Fr cortex. Although these increases were smaller than that observed following fluoxetine treatment, they were still statistically significant $(34 \% ; t=2.93 ; p=0.014)$. In contrast to the changes observed following fluoxetine administration, Bcl-xl, but not Bax, mRNA was clearly upregulated in the hippocampus (45\%; $t=3.14 ; p=0.01)$. Levels of Bax and Bcl-xl were unchanged in Fr cortical tissue
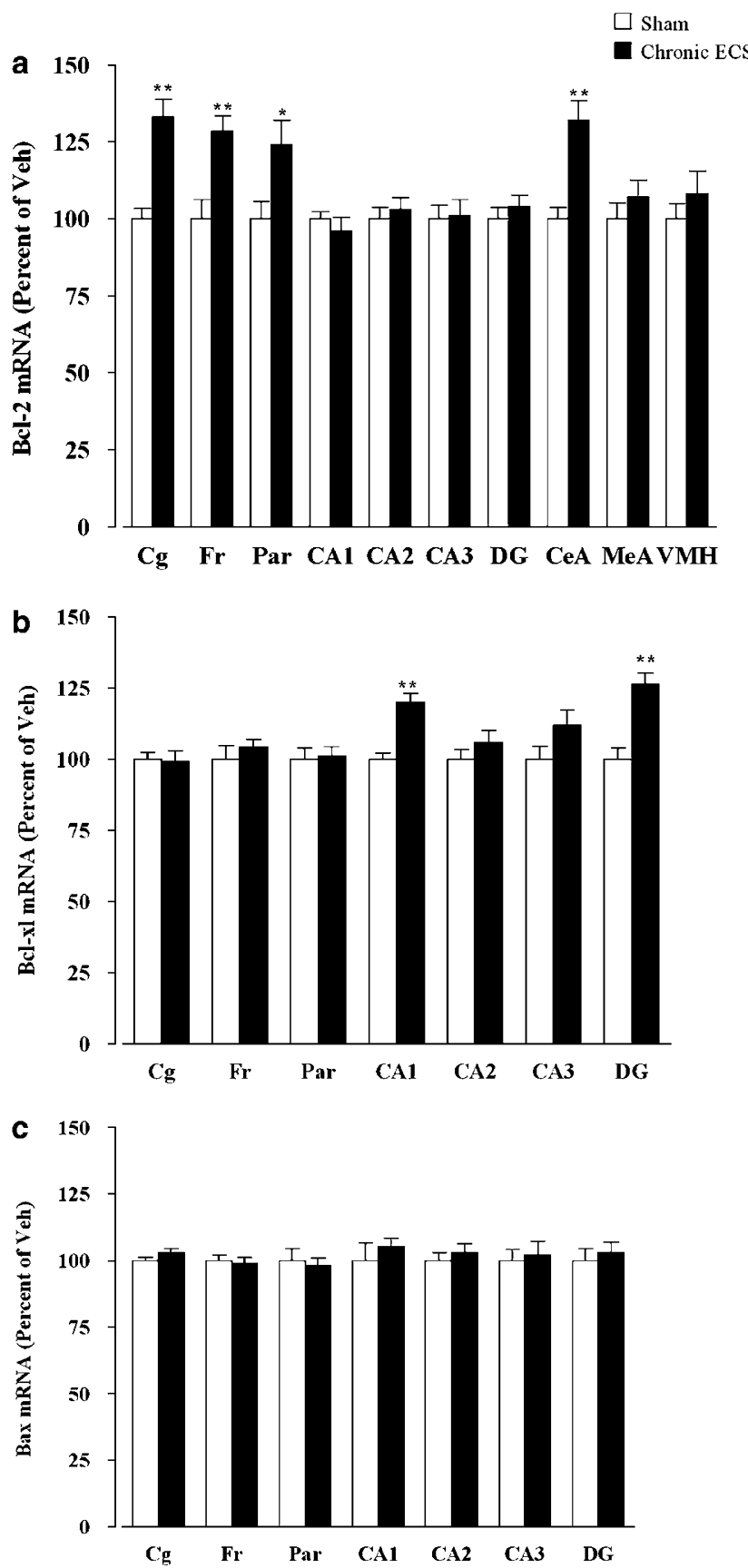

Figure 5 Chronic electroconvulsive seizures (ECS) selectively increase $\mathrm{Bcl}-2$ mRNA expression in the $\mathrm{Cg}$, lateral frontal, and parietal cortices and in the $\mathrm{CeA}$. Bcl-xl mRNA expression is increased in the CAI and DG hippocampal layers. (a) The quantitative analysis of $\mathrm{Bcl}-2, \mathrm{Bcl}-\mathrm{xl}(\mathrm{b})$, and $\mathrm{Bax}$ mRNA (c) expression, expressed as the percentage of change from the control $\pm \operatorname{SEM}\left(n=4\right.$, ${ }^{*} p<0.05$; ** $p<0.01$, two-tailed $t$-test $) . C g$, cingulate cortex; Fr, lateral frontal cortex; Par, parietal cortex; CAI-CA3, pyramidal cell layers of the hippocampus; DG, dentate gyrus hippocampal layer; $\mathrm{CeA}$, central nucleus of the amygdala; MeA, medial amygdaloid nucleus; VMH, ventromedial hypothalamus.

(Figure 6d). These data support the results of our ISH studies and demonstrate that chronic ADT selectively regulates expression of critical apoptotic family members in cerebral cortex and hippocampus. 
Table I Region-Specific Regulation of Apoptotic Genes by Stress and Antidepressant Treatments

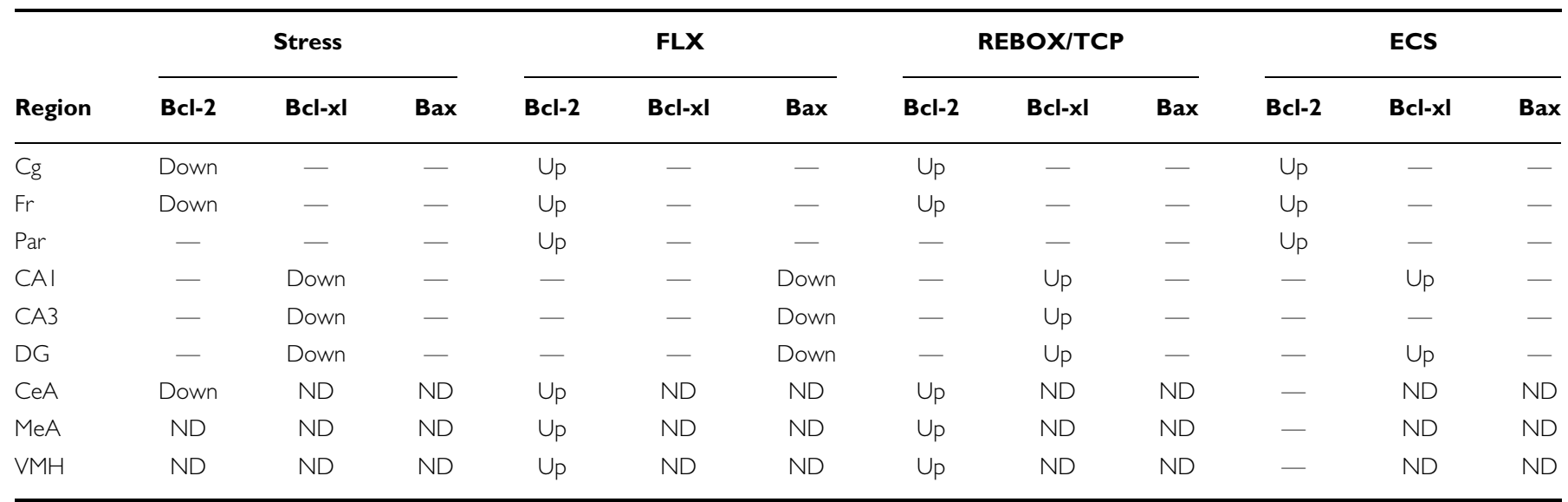

Abbreviations: _- no change; ND, not determined; Cg, anterior cingulate cortex; Fr, lateral frontal cortex; Par, parietal cortex; CAI-CA3, pyramidal cell layers of the hippocampus; DG, dentate gyrus hippocampal layer; CeA, central nucleus of the amygdala; MeA, medial amygdaloid nucleus; VMH, ventromedial hypothalamus; ECS, electroconvulsive seizures; FLX, fluoxetine; REBOX, reboxetine; TCP, tranylcypromine.

\section{DISCUSSION}

Our data provide direct evidence that the Bcl-2 family of pro- and antiapoptotic genes represents an important cellular adaptation in brain following exposure to RUS and ADT treatments. Using ISH and RPA, we demonstrate, for the first time, that there is a clear regional selectivity in the regulation of the three main apoptotic family members in response to stress. In the hippocampus, stress downregulated the expression of Bcl-xl mRNA whereas within limbic regions of the $\mathrm{Cg}$ and $\mathrm{Fr}$ cortical regions, $\mathrm{Bcl}-2$ levels were decreased. Importantly, we report opposite regulation of Bcl-2 mRNA in the CeA by stress and antidepressants and robust induction of Bcl-2 by chemical ADT in the MeA and VMH.

The results show that repeated episodes of unpredictable stress selectively reduce hippocampal Bcl-xl mRNA levels, without altering $\mathrm{Bcl}-2$ mRNA expression in this region. This is in contrast to previous reports demonstrating reduced Bcl-2 immunoreactivity (using a 3-day restraint stress paradigm) or lowered Bcl-2 mRNA expression (using repeated immobilization stress) in the hippocampus (Luo et al, 2004; Yun et al, 2003). An explanation for these discrepancies could be due to the different stress paradigms used as well as methodological techniques. Using immunohistochemistry, we have found that the Bcl-2 antibody used in the restraint stress study is nonspecific due to its labeling Bcl-2 protein in Bcl-2 null mutant mice (C D'Sa, KA Roth, and RS Duman, unpublished observations). Another reason that Bcl-2 gene expression remained unaltered in the hippocampal regions could be due to the low baseline Bcl-2 mRNA levels. Consistent with results of previous work, we observed that in the adult brain, particularly in the hippocampus, Bcl-xl (Hamner et al, 1999) and Bax (Deckwerth et al, 1996) are highly expressed, whereas Bcl2 is present at low levels (Merry et al, 1994). The selective decrease in Bcl-xl within the CA1, CA3, and DG suggests that this antiapoptotic gene, rather than $\mathrm{Bcl}-2$, modulates apoptotic cell death in the hippocampus in response to repeated stress.
In contrast to the hippocampus, less is known about the Fr cortex and other limbic structures following stress exposure. Previous work has shown that exposure to 21 days of restraint stress in rats decreased the length and number of branch points of dendrites in the anterior $\mathrm{Cg}$ and prelimbic cortices (Radley et al, 2004). Neuroimaging and postmortem studies have clearly demonstrated reductions in frontal lobe volumes and decreases in cell number and/ size in anterior $\mathrm{Cg}$, dorsolateral, prefrontal, subgenual, and orbitofrontal cortices (Rajkowska, 2000; Si et al, 2004). The higher cognitive areas of the anterior $\mathrm{Cg}$, Fr cortices, and $\mathrm{CeA}$ where we observed regulation of $\mathrm{Bcl}-2$ correspond well with regions where volumetric and structural impairments are observed in patients with depression.

A novel and important finding in our study is the spatially restricted pattern of Bcl-2 mRNA expression in the CeA as well as its downregulation by stress in this region. Our mRNA expression pattern corresponds well with a recent Bcl-2 immunohistochemical mapping study showing Bcl-2 immunoreactivity in the MeA, as well as in the CeA (Fudge, 2004). In our study, basal levels of Bcl-2 mRNA were very low in the MeA and were not regulated by stress in this region. The amygdala plays a key role in fear conditioning, anxiety, and emotional responses to stress (Carter et al, 2004). Because of the anatomical and functional connections between the DG and the amygdala, abnormal modulation of hippocampal-amygdala pathways may contribute to chronically hypersensitive stress and fear responses (McEwen, 2005). Postmortem studies have shown significant reductions in oligodendrocyte density and glia/ neuron ratio in the amygdala of individuals with major depressive disorder, without a change in neuronal density (Hamidi et al, 2004). In our study, there was no effect of stress on Bax, suggesting that the effects of stress are not mediated by regulation of mRNA of this proapoptotic factor. Rather, our results suggest that decreased expression of the antiapoptotic gene, $\mathrm{Bcl}-2$ and the possible modulation of $\mathrm{Bcl}-2$ protein levels could contribute to a change in the Bcl-2/Bax ratio and the apoptosis/cellular loss observed in cortical and amygdaloid brain regions. 
a

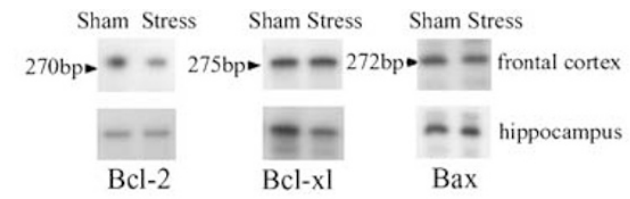

Repeated Unpredictable Stress
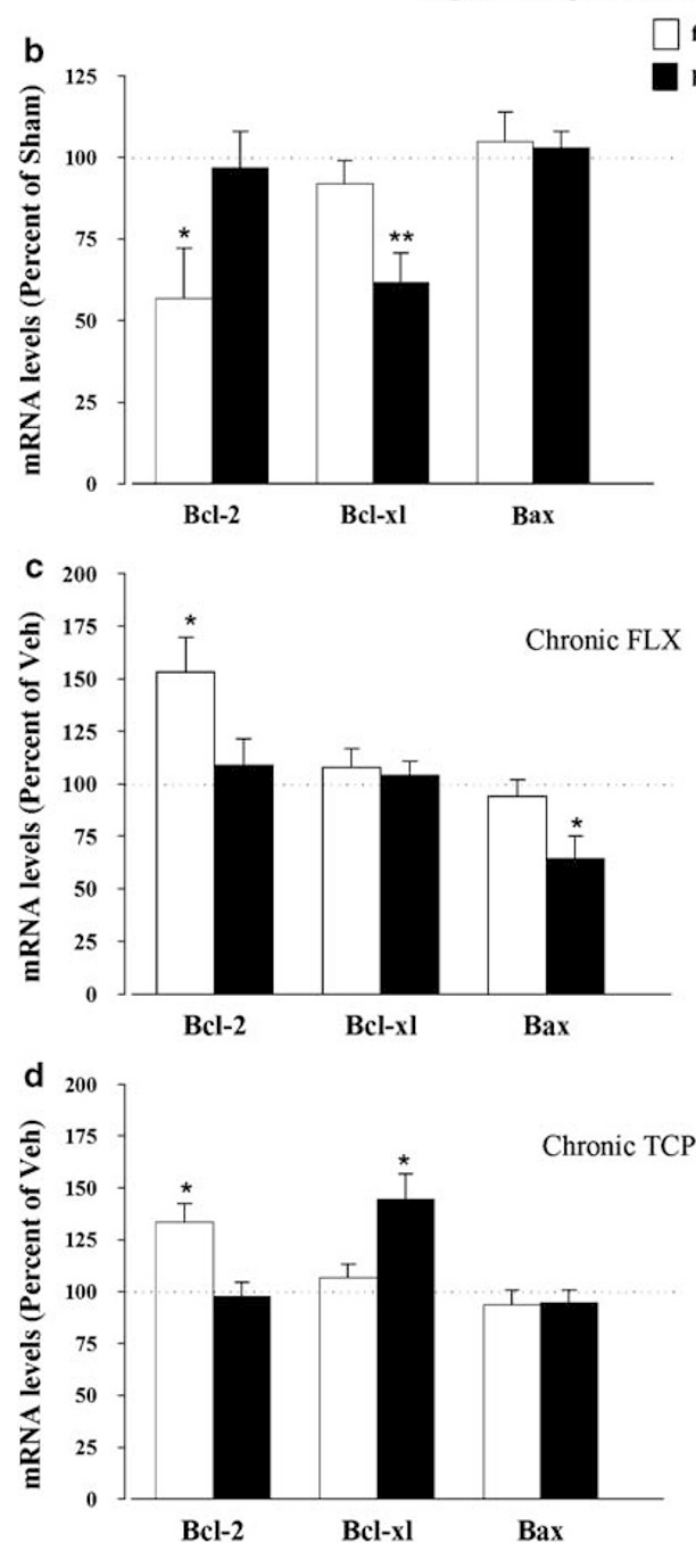

Figure 6 Region-specific decreases in Bcl-2, Bcl-xl, or Bax mRNA levels following exposure to RUS and administration of two different classes of chemical antidepressants. RNAse protection analyses of $\mathrm{BCl}-2$ and $\mathrm{Bcl}-\mathrm{xl}$ show significant changes in Fr cortex and hippocampus. Representative film autoradiograms for sham controls (C) and repeated unpredictable stress (RUS) samples in Fr cortex and hippocampus are presented in (a) above their representative histogram bar in (b). The data are expressed as the percentage of change from the control $\pm \operatorname{SEM}(n=7$, * $p<0.05$; ** $p<0.01$, two-tailed $t$-test). (c) The quantitative analysis of $\mathrm{BCl}-2, \mathrm{Bcl}-\mathrm{xl}$, and $\mathrm{Bax}$ mRNA levels samples in frontal cortex and hippocampus following administration of fluoxetine ( 21 days), expressed as the percentage of change from the control \pm SEM $(n=6$, $* p<0.05$; $* * p<0.01$, two-tailed t-test). (d) The quantitative analysis of $\mathrm{Bcl}-2, \mathrm{Bcl}-\mathrm{xl}$, and $\mathrm{Bax}$ mRNA levels samples in frontal cortex and hippocampus following administration of tranylcypromine for $2 \mathrm{I}$ days, expressed as the percentage of change from the control $\left(n=6,{ }^{*} p<0.05\right.$; ${ }^{*} p<0.01$, two-tailed $t$-test).
Our data demonstrate a complex region-selective regulation of Bcl-2 and Bcl-xl by RUS and raise the possibility that these changes may play a role in mediating the regionspecific apoptotic cell death observed in brain structures following stress exposure. A study using the terminal deoxynucleotidyl transferase biotin-dUTP nick-end labeling (TUNEL) staining, has shown that tree shrews exposed to chronic psychosocial stress exhibited region-specific changes in apoptotic cell death (Lucassen et al, 2001a). Stress increased the number of apoptotic cells in the temporal cortex, but decreased it in the hippocampal pyramidal cell layers (Lucassen et al, 2001a). Particularly, within the hippocampus, there is a close association between apoptosis and neurogenesis and the precise balance drives the continuous turnover of cells in this region (Biebl et al, 2000; Heine et al, 2004). Besides slowing down neurogenesis, stress and steroid hormones temporally reduce the dentate cell turnover, by modulating the ongoing rate of apoptosis (Lucassen et al, 2006; Czeh and Lucassen, 2007). Although, the impact of chronic stress on total hippocampal cell number and volume is modest $(<10 \%)$ and these changes are transient, the functional consequences on dentritic arborization and synaptic plasticity over time could contribute to the structural impairments observed in depressive disorders (Lucassen et al, 2006; Czeh and Lucassen, 2007).

The regional specificity for regulation $\mathrm{Bcl}-2, \mathrm{Bcl}-\mathrm{xl}$, and Bax by different antidepressants is interesting. In general, Bcl-2 mRNA changes by all three chemical antidepressants (ie a 5-HT and norepinephrine-selective reuptake inhibitors, fluoxetine, and reboxetine, respectively, a monoamine oxidase inhibitor, tranylcypromine) as well as the nonchemical ECS were pronounced in the central amygdala and medial Cg cortex, in a direction opposite to that induced by stress. Global cortical regulation in Bcl-2 mRNA was seen by fluoxetine and chronic ECS treatments. An interesting observation was the dramatic increase in Bcl-2 mRNA levels by the different chemical antidepressants in the MeA and $\mathrm{VMH}$ where the magnitude of the changes was greater than for any apoptotic mRNAs observed in the other brains regions. There is considerable evidence that these two regions are key anatomical substrates for social-defensive behaviors and feeding-related satiety pathways (Swanson, 1999). These areas are only recently beginning to be explored in adaptive responses to ADT (Georgescu et al, 2005). Our data demonstrating regulation of Bcl-2 in these areas by chemical antidepressants, and not ECS, are novel findings defining a hypothalamic-limbic brain circuitry that is implicated in adaptive responses to chemical antidepressant action. Hypothalamic and amygdaloid abnormalities contribute to alterations in appetite, libido, and autonomic function possibly contributing to the altered mood/anhedonia observed in depressed patients (Nemeroff, 2003; Nestler and Carlezon, 2006). It is possible that induction of Bcl-2 mRNA in this region represents an adaptation to normalize these abnormalities. The increased Bcl-2 expression in the amygdala is noteworthy in context of a recent study showing that mice with a targeted mutation of the Bcl2 gene demonstrated significant increases in anxiety-like behaviors in animal models (Einat et al, 2005).

Our results also showed that reboxetine, tranylcypromine, and ECS increased Bcl-xl in the CA1 and DG, effects that are 
opposite to the actions of stress. These drugs are known to increase the proliferation and survival of newborn neurons in the DG of adult animals (Malberg et al, 2000; Nakagawa et al, 2002), and it is possible that upregulation of $\mathrm{Bcl}-\mathrm{xl}$ contributes to the cell survival effects of antidepressants. Unlike Bcl-2, the antiapoptotic Bcl-xl is highly expressed in the adult hippocampus under basal conditions and may play a role in modulating apoptosis in this region in vivo. In a recent report, Chiou et al (2006) demonstrated that hippocampus-derived neural stem cells treated with the ADT, moclobemide (an MAO inhibitor) differentiated in vitro into neural cells that had features of serotonergic neurons and required the ERK signaling pathway; moreover, this process was correlated with a corresponding increase in Bcl-2 and Bcl-xl mRNA expression (Chiou et al, 2006). In another study, chronic administration of the ADT, tianeptine (a serotonin releaser), significantly reduced apoptosis in the DG and temporal cortex, in control as well as in stressed rats, although no changes were observed in the pyramidal hippocampal layers (Lucassen et al, 2004). Although yet to be tested, it is conceivable that the ADTinduced increase in Bcl-xl expression in the hippocampus may not correspond with a significant change in the ongoing apoptotic cell death in the hippocampus. Nevertheless, it is well documented that independent of its neurotrophic effects, Bcl-xl influences synaptic stability and modulates neurotransmission (Jonas et al, 2003). Our data raise the possibility that the ADT-mediated Bcl-xl upregulation in the hippocampus may also contribute to synaptic stability in this region.

Interestingly, chronic fluoxetine administration did not influence Bcl-2 or Bcl-xl expression in the CA1 and DG but it was the only antidepressant that decreased levels of the proapoptotic protein, Bax in CA1, CA3, and DG subfields of hippocampus. It would be interesting in future studies to determine if the fluoxetine-induced downregulation in Bax expression translates into a corresponding decrease in Bax protein levels as well as a decrease in ongoing rate of apoptotic cellular death. The apoptotic process is critically controlled by the $\mathrm{Bcl}-2 / \mathrm{Bax}$ ratio and $\mathrm{Bcl}-\mathrm{xl} / \mathrm{Bax}$ ratios. $\mathrm{A}$ change in any one of these proteins could alter this ratio triggering cell survival or cell death. Excess amounts of proapoptotic Bax in its active form can also directly induce cytochrome $c$ release, resulting in formation of the apoptosome complex composed of Apaf-1, caspase-9, and ATP, triggering cell death (Korhonen et al, 2003; Roucou and Martinou, 2001). From studies using Bax null mutant mice, it has recently been shown that in the adult hippocampus, programmed cell death as well as proliferation, migration, and maturation of adult-generated DG neurons is mainly dependent on Bax (Sun et al, 2004). On the other hand, the neuroprotective effects of fluoxetine in the hippocampus are only recently coming to light. In a maternal separation paradigm, fluoxetine treatment reversed the stress-induced increases in TUNEL immunoreactive cells in the hippocampus DG (Lee et al, 2001).

The reasons for these regional differences between fluoxetine and the other drugs in regulating Bcl-xl and Bax levels in the hippocampus are unknown. The hippocampus receives diffuse projections from both the NE and 5-HT neurotransmitter systems (Blier and de Montigny, 1994). It is possible that a different dose of drug may be required. Another explanation is that the $\mathrm{Bcl}-\mathrm{xl}$ responses to fluoxetine treatment and the Bax responses to stress, reboxetine, tranylcypromine, and ECS treatments may be associated with translational and post-translational changes in Bax protein or the translocation of Bax from one membrane compartment to another. Further co-immunoprecipitation, subcellular fractionation, and immunoblotting studies will be necessary to study the effect of stress and different ADTs on post-translational and translocation changes in Bcl-2, Bcl-xl, and Bax proteins.

The molecular and cellular mechanisms underlying the differential regulation of $\mathrm{Bcl}-2$ and $\mathrm{Bcl}-\mathrm{xl}$ mRNAs is unknown. In vitro studies have shown that the $\mathrm{Bcl}-\mathrm{xl}$ gene promoter is regulated by $\mathrm{NF}-\kappa \mathrm{B}$ and its expression is regulated by the MAPK signaling pathway (Marinari et al, 2004; Yu et al, 2005) The Bcl-2 promoter contains a CRE that mediates its responsivity to the transcription factor (CREB) (Bonni et al, 1999; Riccio et al, 1999). Withdrawal of trophic support as well as an inhibition of CREB transcription triggers apoptosis in neurons. Stress, glucocorticoids, and antidepressants exert opposing effects on neurotrophic factors such as nerve growth factor and BDNF that maintain the survival and function of brain cells by suppressing cellular apoptotic signaling (Manji and Duman, 2001). Exposure to stress downregulates BDNF levels in the amygdala, hippocampus, and cortex (Pizarro et al, 2004; Smith et al, 1995). The known signaling pathways that mediate the effects of the neurotrophic factors on Bcl-2 and $\mathrm{Bcl}-\mathrm{xl}$ are the Rsk/MAP pathway, JNK pathway, and the PI3K/AKT pathway (Manji and Duman, 2001; Bonni et al, 1999; Riccio et al, 1999). Stressors such as forced-swim and restraint stress induce activation of the MKK4-JNK signaling pathway in the hippocampus, amygdala, and hypothalamus (Liu et al, 2004). Although stimulation of this signaling pathway acutely influences the phosphorylation states and membrane translocations of the apoptotic proteins, it is possible that long-term sustained stimulation of this pathway as well as circulating glucocorticoids caused by chronic stress downregulates $\mathrm{Bcl}-2$ and $\mathrm{Bcl}-\mathrm{xl}$ gene expression as a compensatory response. ADT on the other hand, increases BNDF levels and blocks the downregulation of this factor by stress (Nibuya et al, 1995). Chronic ADT upregulates the CAMP-CREB cascade and CRE-mediated gene transcription in the cortex, amygdala, hypothalamus, and hippocampus (Frechilla et al, 1998; Thome et al, 2000). These are the same areas where we observed an increase in Bcl-2 and Bcl-xl/mRNAs. The long-term sustained upregulation of $\mathrm{CREB}$ and $\mathrm{BDNF}$ could increase $\mathrm{Bcl}-2$ gene transcription in the cortex, hypothalamus, and amygdala and account for the increased expression observed in our study.

In summary, the results of the present study provide evidence that stress and antidepressant drugs exert opposing actions on the expression of Bcl-2, Bcl-xl, and Bax in a region-specific manner in limbic brain structures. We acknowledge that the modest changes in mRNA levels observed in our study do leave open the question of whether the changes in Bcl-2 family genes mRNA are essential and/ or sufficient for opposing behavioral changes caused by RUS and antidepressants. We understand that the juxtaposition of RUS and antidepressants in this study is based on the underlying assumption that RUS is, at least in part, a 
valid animal model of depression (Henn and Vollmayr, 2005). Our data suggest that there may be a relationship between stress and ADT through their opposing effects on the apoptotic gene expression.

A major goal of future work will be to examine whether ADT reverses the effects of stress on pro- and antiapoptotic gene expression in this RUS model as well as in other animal models of depression. Another critical question in future studies would be to examine the cell types in which these mRNA changes take place, the functional consequences of apoptotic gene regulation in particular brain areas, and whether these mRNA changes actually correspond with alterations in apoptotic cell death. Besides the TUNEL staining currently used, more precise staining techniques such as activated caspase assays would be needed to address this issue. Finally, it would be important to determine whether equivalent changes occur in apoptotic protein levels and if translocation and post-translation modifications of these proteins take place. It is possible that the alterations in levels of mRNA for anti- and proapoptotic factors observed in the present study reflect early stages of cell survival and/or apoptosis, and that there may not be corresponding changes in cell death until much longer periods of stress or ADT.

\section{ACKNOWLEDGEMENTS}

We thank Dr Jennifer Warner for providing the reboxetinetreated brain sections, Drs Cleta D'Sa and Kevin Roth for suggestions, assistance, and helpful comments, Dr Leo Buss for support, and Kathryn Stellitano for assistance with the RUS paradigm. This work was supported by a NARSAD Young Investigator Award to $\mathrm{CD}$ and a Program Project Grant from NIMH to DSR and RSD.

\section{DISCLOSURE/CONFLICT OF INTEREST}

The authors declare that, except for income received from our primary employers, no financial support or compensation has been received from any individual or corporate entity over the past 3 years for research or professional service and there are no personal financial holdings that could be perceived as constituting a potential conflict of interests.

\section{REFERENCES}

Biebl M, Cooper CM, Winkler J, Kuhn HG (2000). Analysis of neurogenesis and programmed cell death reveals a self-renewing capacity in the adult rat brain. Neurosci Lett 291: 17-20.

Blier P, de Montigny C (1994). Current advances and trends in the treatment of depression. TIPS 18: 220-226.

Bonni A, Brunet A, West AE, Datta SR, Takasu MA, Greenberg ME (1999). Cell survival promoted by the Ras-MAPK signaling pathway by transcription-dependent and -independent mechanisms. Science 286: 1358-1362.

Bowley MP, Drevets WC, Ongur D, Price JL (2002). Low glial numbers in the amygdala in major depressive disorder. Biol Psychiatry 52: 404-412.

Carter RN, Pinnock SB, Herbert J (2004). Does the amygdala modulate adaptation to repeated stress? Neuroscience 126: 9-19.
Chen G, Zeng WZ, Yuan PX, Huang LD, Jiang YM, Zhao ZH et al (1999). The mood-stabilizing agents lithium and valproate robustly increase the levels of the neuroprotective protein bcl-2 in the CNS. J Neurochem 72: 879-882.

Chiou S-H, Ku H-H, Tsai T-H, Lin H-L, Chen L-H, Chien C-S et al (2006). Moclobemide upregulated Bcl-2 expression and induced neural stem cell differentiation into serotonergic neuron via extracellular-regulated kinase pathway. $B r J$ Pharmacol 148: 563-564.

Cory S, Adams JM (2002). The Bcl2 family: regulators of the cellular life-or-death switch. Nat Rev Cancer 2: 647-656.

Cotter D, Mackay D, Landau S, Kerwin R, Everall I (2001). Reduced glial cell density and neuronal size in the anterior cingulate cortex in major depressive disorder. Arch Gen Psychiatry 58: 545-553.

Czeh B, Lucassen PJ (2007). What causes the hippocampal volume decreases in depression? Are neurogenesis, glial changes and apoptosis implicated? Eur Arch Psych Clin Neurosci 10: 728-738.

Czeh B, Michaelis T, Watanabe T, Frahm J, de Biurrun G, van Kampen M et al (2001). Stress-induced changes in cerebral metabolites, hippocampal volume, and cell proliferation are prevented by antidepressant treatment with tianeptine. Proc Natl Acad Sci USA 98: 12796-12801.

Deckwerth TL, Elliott JL, Knudson CM, Johnson Jr EM, Snider WD, Korsmeyer SJ (1996). BAX is required for neuronal death after trophic factor deprivation and during development. Neuron 17: 401-411.

D'Sa C, Duman RS (2002). Antidepressants and neuroplasticity. Bipolar Disord 4: 183-194.

D'Sa C, Tolbert LM, Conti M, Duman RS (2002). Regulation of cAMP-specific phosphodiesterases type 4B and 4D (PDE4) splice variants by cAMP signaling in primary cortical neurons. J Neurochem 81: 745-757.

Dulawa SC, Hen R (2005). Recent advances in animal models of chronic antidepressant effects: the novelty-induced hypophagia test. Neurosci Biobehav Rev 29: 771-783.

Duman RS (2004). A case of neuronal life and death? Biol Psychiatry 56: 140-145.

Duman RS, Monteggia LM (2006). A neurotrophic model for stress-related mood disorders. Biol Psychiatry 59: 1116-1127.

Einat H, Yuan P, Manji HK (2005). Increased anxiety-like behaviors and mitochondrial dysfunction in mice with targeted mutation of the Bcl-2 gene: further support for the involvement of mitochondrial function in anxiety disorders. Behav Brain Res 165: $172-180$.

Frechilla D, Otano A, Del Rio J (1998). Effect of chronic antidepressant treatment on transcription factor binding activity in rat hippocampus and frontal cortex. Prog Neuropsychopharmacol Biol Psychiatry 22: 787-802.

Fudge JL (2004). Bcl-2 immunoreactive neurons are differentially distributed in subregions of the amygdala and hippocampus of the adult macaque. Neuroscience 127: 539-556.

Georgescu D, Sears RM, Hommel JD, Barrot M, Bolanos CA, Marsh DJ et al (2005). The hypothalamic neuropeptide melaninconcentrating hormone acts in the nucleus accumbens to modulate feeding behavior and forced-swim performance. J Neurosci 25: 2933-2940.

Gold SJ, Ni YG, Dohlman HG, Nestler EJ (1997). Regulators of G-protein signaling (RGS) proteins: region-specific expression of nine subtypes in rat brain. J Neurosci 17: 8024-8037.

Gould E, Tanapat P, McEwen BS, Flugge G, Fuchs E (1998). Proliferation of granule cell precursors in the dentate gyrus of adult monkeys is diminished by stress. Proc Natl Acad Sci USA 95: $3168-3171$.

Haile CN, GrandPre R, Kosten TA (2001). Chronic unpredictable stress, but not chronic predictable stress, enhances the sensitivity to the behavioral effects of cocaine in rats. Psychopharmacology 154: 213-220. 
Hamidi M, Drevets WC, Price JL (2004). Glial reduction in amygdala in major depressive disorder is due to oligodendrocytes. Biol Psychiatry 55: 563-569.

Hamner S, Skoglosa Y, Lindholm D (1999). Differential expression of bcl-w and bcl-x messenger RNA in the developing and adult rat nervous system. Neuroscience 91: 673-684.

Harlan J, Chen Y, Gubbins E, Mueller R, Roch J-M, Walter K et al (2006). Variants in Apaf-1 segregating with major depression promote apoptosome function. Mol Psychiatry 11: 76-85.

Heine VM, Maslam S, Zareno J, Joels M, Lucassen PJ (2004). Suppressed proliferation and apoptotic changes in the rat dentate gyrus after acute and chronic stress are reversible. Eur J Neurosci 19: 131-144.

Henn FA, Vollmayr B (2005). Stress models of depression: forming genetically vulnerable strains. Neurosci Biobehav Rev 29: 799-804.

Joels M, Karst H, Alfarez D, Heine VM, Quin Y, Riel EV et al (2004). Effects of chronic stress on structure and cell function in rat hippocampus and hypothalamus. Stress 7: 221-231.

Jonas EA, Hoit D, Hickman JA, Brandt TA, Polster BM, Fannjiang $Y$ et al (2003). Modulation of synaptic transmission by the BCL-2 family protein BCL-xL. J Neurosci 23: 8423-8431.

Kodama M, Fujioka T, Duman RS (2004). Chronic olanzapine or fluoxetine administration increases cell proliferation in hippocampus and prefrontal cortex of adult rat. Biol Psychiatry 56: 570-580.

Korhonen L, Belluardo N, Mudo G, Lindholm D (2003). Increase in Bcl-2 phosphorylation and reduced levels of BH3-only Bcl-2 family proteins in kainic acid-mediated neuronal death in the rat brain. Eur J Neurosci 18: 1121-1134.

Lee HJ, Kim JW, Yim SV, Kim MJ, Kim SA, Kim YJ et al (2001). Fluoxetine enhances cell proliferation and prevents apoptosis in dentate gyrus of maternally separated rats. Mol Psychiatry 6: $725-728$

Lindsten T, Zong W-X, Thompson CB (2005). Defining the role of the Bcl-2 family of proteins in the nervous system. Neuroscientist 11: $10-15$.

Liu YF, Bertram K, Perides G, McEwen BS, Wang D (2004). Stress induces activation of stress-activated kinases in the mouse brain. J Neurochem 89: 1034-1043.

Lucassen PJ, Fuchs E, Czeh B (2004). Antidepressant treatment with tianeptine reduces apoptosis in the hippocampal dentate gyrus and temporal cortex. Biol Psychiatry 55: 789-796.

Lucassen PJ, Heine VM, Muller MB, van der Beek EM, Wiegant VM, De Kloet ER et al (2006). Stress, depression and hippocampal apoptosis. CNS Neurol Disord Drug Targets 5: 531-546.

Lucassen PJ, Muller MB, Holsboer F, Bauer J, Holtrop A, Wouda J et al (2001b). Hippocampal apoptosis in major depression is a minor event and absent from subareas at risk for glucocorticoid overexposure. Am J Pathol 158: 453-468.

Lucassen PJ, Vollmann-Honsdorf GK, Gleisberg M, Czeh B, De Kloet ER, Fuchs E (2001a). Chronic psychosocial stress differentially affects apoptosis in hippocampal subregions and cortex of the adult tree shrew. Eur J Neurosci 14: 161-166.

Luo C, Xu H, Li XM (2004). Post-stress changes in BDNF and Bcl-2 immunoreactivities in hippocampal neurons: effect of chronic administration of olanzapine. Brain Res 1025: 194-202.

MacQueen GM, Ramakrishnan K, Ratnasingan R, Chen B, Young LT (2003). Desipramine treatment reduces the long-term behavioral and neurochemical sequelae of early-life maternal separation. Int J Neuropsychopharmacol 6: 391-396.

Magarinos AM, McEwen BS, Flugge G, Fuchs E (1996). Chronic psychosocial stress causes apical dendritic atrophy of hippocampal CA3 pyramidal neurons in subordinate tree shrews. J Neurosci 16: 3534-3540.

Malberg JE, Eisch AJ, Nestler EJ, Duman RS (2000). Chronic antidepressant treatment increases neurogenesis in adult hippocampus. J Neurosci 20: 9104-9110.
Manji HK, Drevets WC, Charney DS (2001). The cellular neurobiology of depression. Nat Med 7: 541-547.

Manji HK, Duman RS (2001). Impairments of neuroplasticity and cellular resilience in severe mood disorders: implications for the development of novel therapeutics. Psychopharmacol Bull 35: $5-49$.

Marinari B, Costanzo A, Marzano V, Piccolella E, Tuosto L (2004). CD28 delivers a unique signal leading to the selective recruitment of RelA and p52 NF-kappaB subunits on IL-8 and Bcl-xL gene promoters. Proc Natl Acad Sci USA 101: 6098-6103.

Mayberg HS (2003). Positron emission tomography imaging in depression: a neural systems perspective. Neuroimaging Clin $N$ Am 13: 805-815.

McEwen BS (2005). Glucocorticoids, depression, and mood disorders: structural remodeling in the brain. Metabolism 54: 20-33.

Merry DE, Veis DJ, Hickey WF, Korsmeyer SJ (1994). Bcl-2 protein expression is widespread in the developing nervous system and retained in the adult PNS. Development 120: 301-311.

Nakagawa S, Kim JE, Lee R, Malberg JE, Chen J, Steffen C et al (2002). Regulation of neurogenesis in adult mouse hippocampus by cAMP and the cAMP response element-binding protein. J Neurosci 22: 3673-3682.

Nemeroff CB (2003). Advancing the treatment of mood and anxiety disorders: the first 10 years' experience with paroxetine. Psychopharmacol Bull 37(Suppl 1): 6-7.

Nestler EJ, Carlezon Jr WA (2006). The mesolimbic dopamine reward circuit in depression. Biol Psychiatry 59: 1151-1159.

Nibuya M, Morinobu S, Duman RS (1995). Regulation of BDNF and trkB mRNA in rat brain by chronic electroconvulsive seizure and antidepressant drug treatments. J Neurosci 15: 7539-7547.

Nishimura K, Makino S, Tanaka Y, Kaneda T, Hashimoto K (2004). Altered expression of p53 mRNA in the brain and pituitary during repeated immobilization stress: negative correlation with glucocorticoid receptor mRNA levels. J Neuroendocrinol 16: $84-91$.

Ongur D, Drevets WC, Price JL (1998). Glial reduction in the subgenual prefrontal cortex in mood disorders. Proc Natl Acad Sci USA 95: 13290-13295.

Ortiz J, Fitzgerald LW, Lane S, Terwilliger R, Nestler EJ (1996). Biochemical adaptations in the mesolimbic dopamine system in response to repeated stress. Neuropsychopharmacology 14: 443-452.

Paxinos G, Watson C (1986). The Rat Brain in Stereotaxic Coordinates, 2nd edn, Academic Press: London.

Perrotti LI, Hadeishi Y, Ulery PG, Barrot M, Monteggia L, Duman RS et al (2004). Induction of deltaFosB in reward-related brain structures after chronic stress. J Neurosci 24: 10594-10602.

Pizarro JM, Lumley LA, Medina W, Robison CL, Chang WE, Alagappan A et al (2004). Acute social defeat reduces neurotrophin expression in brain cortical and subcortical areas in mice. Brain Res 1025: 10-20.

Radley JJ, Sisti HM, Hao J, Rocher AB, McCall T, Hof PR et al (2004). Chronic behavioral stress induces apical dendritic reorganization in pyramidal neurons of the medial prefrontal cortex. Neuroscience 125: 1-6.

Rajkowska G (2000). Postmortem studies in mood disorders indicate altered numbers of neurons and glial cells. Biol Psychiatry 48: 766-777.

Rajkowska G, Miguel-Hidalgo JJ, Wei J, Dilley G, Pittman SD, Meltzer HY et al (1999). Morphometric evidence for neuronal and glial prefrontal cell pathology in major depression. Biol Psychiatry 45: 1085-1098.

Riccio A, Ahn S, Davenport CM, Blendy JA, Ginty DD (1999). Mediation by a CREB family transcription factor of NGF-dependent survival of sympathetic neurons. Science 286: $2358-2361$ 
Roucou X, Martinou JC (2001). Conformational change of Bax: a question of life or death. Cell Death Differ 8: 875-877.

Sapolsky RM (2000). The possibility of neurotoxicity in the hippocampus in major depression: a primer on neuron death. Biol Psychiatry 48: 755-765.

Sheline YI, Gado MH, Kraemer HC (2003). Untreated depression and hippocampal volume loss. Am J Psychiatry 160: 1516-1518.

Shirayama Y, Chen AC, Nakagawa S, Russell DS, Duman RS (2002). Brain-derived neurotrophic factor produces antidepressant effects in behavioral models of depression. J Neurosci 22: 3251-3261.

Si X, Miguel-Hidalgo JJ, O’Dwyer G, Stockmeier CA, Rajkowska G (2004). Age-dependent reductions in the level of glial fibrillary acidic protein in the prefrontal cortex in major depression. Neuropsychopharmacology 29: 2088-2096.

Smith MA, Makino S, Kvetnansky R, Post RM (1995). Stress and glucocorticoids affect the expression of brain-derived neurotrophic factor and neurotrophin-3 mRNAs in the hippocampus. J Neurosci 15: 1768-1777.

Stockmeier C, Mahajan GJ, Konick LC, Overholser JC, Jurjus GJ, Meltzer HY et al (2004). Cellular changes in the postmortem hippocampus in major depression. Biol Psychiatry 56: 640-650.

Sun W, Winseck A, Vinsant S, Park OH, Kim H, Oppenheim RW (2004). Programmed cell death of adult-generated hippocampal neurons is mediated by the proapoptotic gene Bax. J Neurosci 24: 11205-11213.

Swanson LW (1999). The neuroanatomy revolution of the 1970s and the hypothalamus. Brain Res Bull 50: 397-399.
Thome J, Sakai N, Shin K, Steffen C, Zhang YJ, Impey S et al (2000). cAMP response element-mediated gene transcription is upregulated by chronic antidepressant treatment. J Neurosci 20: 4030-4036.

Vyas A, Mitra R, Shankaranarayana Rao BS, Chattarji S (2002). Chronic stress induces contrasting patterns of dendritic remodeling in hippocampal and amygdaloid neurons. J Neurosci 22: 6810-6818.

Vythilingam M, Vermetten E, Anderson GM, Luckenbaugh D, Anderson ER, Snow J et al (2004). Hippocampal volume, memory, and cortisol status in major depressive disorder: effects of treatment. Biol Psychiatry 56: 101-112.

Willner P, Muscat R, Papp M (1992). Chronic mild stress-induced anhedonia: a realistic animal model of depression. Neurosci Biobehav Rev 16: 525-534.

Xu H, Richardson JS, Li X-M (2003). Dose-related effects of chronic antidepressants on neuroprotective proteins BDNF, $\mathrm{Bcl}-2$ and $\mathrm{Cu} / \mathrm{Zn}-\mathrm{SOD}$ in rat hippocampus. Neuropsychopharmacology 28: 53-62.

Yu YL, Chiang YJ, Chen YC, Papetti M, Juo CG, Skoultchi AI et al (2005). MAP kinase-mediated phosphorylation of GATA-1 promotes Bcl-XL expression and cell survival. J Biol Chem 280: 29533-29542.

Yun SJ, Lee DJ, Kim MO, Jung B, Kim SO, Sohn NW et al (2003). Reduction but not cleavage of poly (ADP-ribose) polymerase during stress-mediated cell death in the rat hippocampus. Neuroreport 14: 935-939. 